Published in "Sedimentology 66(2): 480-512, 2019" which should be cited to refer to this work.

\title{
Pleistocene sea-floor fibrous crusts and spherulites in the Danakil Depression (Afar, Ethiopia)
}

\author{
DAVID JARAMILLO-VOGEL *, ANNELEEN FOUBERT*, JUAN CARLOS BRAGA $\dagger$, \\ JEAN-CHARLES SCHAEGIS *, BALEMWAL ATNAFU \\ TESFAYE KIDANE $\$$ \\ *Department of Geosciences, University of Fribourg, Ch. Du Musée 6, 1700 Fribourg, Switzerland \\ (E-mail: david.jaramillovogel@unifr.ch) \\ $\dagger$ Departamento de Estratigrafía y Paleontología, Universidad de Granada, Campus Fuentenueva, \\ 18002 Granada, Spain \\ $\$$ School of Earth Sciences, Addis Ababa University, Addis Ababa, Ethiopia \\ $\S$ School of Agricultural, Earth and Environmental Sciences, College of Agriculture, Engineering and \\ Sciences, University of Kwazulu-Natal, Westville Campus, Durban, South Africa
}

\begin{abstract}
Pleistocene fibrous aragonite fabrics, including crusts and spherules, occur in the Danakil Depression (Afar, Ethiopia) following the deposition of two distinctive Middle and Late Pleistocene coralgal reef units and pre-dating the precipitation of evaporites. Crusts on top of the oldest reef unit (Marine Isotope Stage 7) cover and fill cavities within a red algal framework. The younger aragonite crusts directly cover coralgal bioherms (Marine Isotope Stage 5) and associated deposits. Their stratigraphic position between marine and evaporitic deposits, and their association to euryhaline molluscs, suggest that the crusts and spherules formed in restricted semi-enclosed conditions. The availability of hard substrate controls crust formation with crusts more often found on steep palaeoslopes, from sea level up to at least $80 \mathrm{~m}$ depth, while spherules mainly occur associated with mobile substrate. Crusts reach up to $30 \mathrm{~cm}$ in thickness and can be microdigitate, columnar (branching and non-branching) or non-columnar, with laminated and non-laminated fabrics. Two different lamination types are found within the crystalline fabrics: (i) isopachous lamination; and (ii) irregular lamination. These two types of lamination can be distinguished by the organization of the aragonite fibres, as well as the lateral continuity of the laminae. Scanning electron microscopy with energy dispersive X-ray spectroscopy analyses on well-preserved samples revealed the presence of Mg-silicate laminae intercalated with fibrous aragonite, as well as Mg-silicate aggregates closely associated with the fibrous aragonite crusts and spherules. The variety of observed fabrics results from a continuum of abiotic and microbial processes and, thus, reflects the tight interaction between microbially mediated and abiotic mineralization mechanisms. These are the youngest known isopachously laminated, digitate and columnar branching fibrous crusts associated with a transition from marine to evaporitic conditions. Understanding the context of formation of these deposits in Afar can help to better interpret the depositional environment of the widespread Precambrian sea-floor precipitates.
\end{abstract}

Keywords Danakil Depression, fibrous aragonite crust, Mg-silicate, sea-floor crust, spherulite, stromatolite. 


\section{INTRODUCTION}

Since Kalkowsky (1908) introduced the term stromatolite to describe layered lacustrine rocks of the Early Triassic in northern Germany, and interpreted this type of deposit as being formed by 'simply organized plant-like organisms' (Riding, 2011), there has been a debate as to whether, in all cases, similar laminated structures are of biogenic (microbial) origin, or whether some of them (especially in the Precambrian) should be regarded as abiotic sea-floor cements. It is now widely accepted that sparry crusts including isopachously laminated, botryoidal, microdigitate stromatolitic, dendritic and herringbone calcite fabrics were largely formed abiotically (Grotzinger, 1989; Grotzinger \& Rothman, 1996; Sami \& James, 1996; Grotzinger \& Knoll, 1999; Pope et al., 2000; Riding, 2008). By contrast, irregularly laminated and clotted fabrics, often containing micritic and peloidal laminae, are considered microbial or hybrid in origin (i.e. where both biotic and abiotic processes are involved; Pope et al., 2000; see Riding, 2008, for discussion).

Throughout the geological record, stromatolites formed during transitions between marine and evaporitic conditions due to basin isolation, resulting in increased temperature, salinity and eventually anoxic conditions, creating ecological restriction and an opportunity for stromatolites to grow (Pope et al., 2000). Pope et al. (2000) discussed that, although stromatolites characterized by thin, isopachous lamination and radial fibrous textures are common in the Precambrian and Palaeozoic, they are rare in transitional facies in Jurassic and younger evaporite basins where they have been superseded by peloidal and clastic textures. Since the early Palaeozoic, thrombolitic fabrics are often associated with stromatolites (Kennard \& James, 1986; Braga et al., 1995; Feldmann \& McKenzie, 1997).

In order to better understand the role of microbial versus abiotic precipitation in sparry laminated authigenic deposits, it is important to study their mode of formation and associated fabrics prior to diagenesis. Therefore, one of the main objectives of the scientific community working on stromatolites has been to find analogues of such facies in modern environments. This has proven to be difficult because comparable deposits are scarce in modern seas. The best known modern marine stromatolite examples grow in high-energy subtidal settings in the Bahamas (Dill et al., 1986; Reid \& Browne, 1991;
Riding et al., 1991; Reid et al., 2000) and in Shark Bay (Western Australia) (Logan, 1961; Awramik \& Riding, 1988; Reid et al., 2003; Allen et al., 2009; Suosaari et al., 2016). The Bahamian stromatolites, however, differ in microfabrics from the majority of Precambrian stromatolites, as they are mainly produced by trapping and binding of bioclasts, peloids and ooids through filamentous cyanobacteria, resulting in crudely laminated grainy fabrics. These trapped particles are subsequently stabilized by the precipitation of micritic aragonite (Dravis, 1983; Dill et al., 1986; Reid et al., 1995, 2000). The precipitation within these grainy stromatolites has been attributed to the activity of sulphate-reducing bacteria, resulting in increased alkalinity and $\mathrm{Ca}^{2+}$ release from extracellular polymeric substances (EPS) after degradation of the organic filaments (Visscher et al., 1998, 2000; Reid et al., 2000; Paerl et al., 2001; Dupraz et al., 2009). Recent research in Hamelin Pool (Shark Bay) has shown pervasive micrite precipitation in stromatolite framework formation, comprising 20 to $50 \%$ of most stromatolites and up to $80 \%$ in some heads (Suosaari et al., 2016). The influence of microbial activity in micrite precipitation is widely accepted among researchers but the exact mechanism is unclear. Heterotrophic activity, photosynthetic $\mathrm{CO}_{2}$ uptake, release of EPS-bound calcium during remineralization and influx of highly alkaline ground water can all contribute to carbonate precipitation (Suosaari et al., 2016). The precipitated micrite lamination of some stromatolites in Hamelin Pool is similar to many micritic Precambrian stromatolites (Suosaari et al., 2016) but, as in the Bahamian stromatolites, sparry fabrics are not observed.

Shapes and sizes of modern stromatolites are comparable to only a small fraction of their Archean and Proterozoic counterparts. For example, the diameter of most modern marine stromatolites exceeds $20 \mathrm{~cm}$, while more than half of the columnar stromatolites found in the geological record, including most of the Phanerozoic examples, have a diameter smaller than $5 \mathrm{~cm}$, with only $5 \%$ having diameters exceeding $30 \mathrm{~cm}$ (Grotzinger, 1989; Grotzinger \& James, 2000; Raaben, 2006; Bosak et al., 2013). Additionally, branching is very uncommon in modern marine stromatolites, yet it is a common feature in the Proterozoic as well as in Late Archean stromatolites (Bosak et al., 2013) believed to have formed in highly alkaline early ocean waters (Kempe \& Degens, 1985; Kempe \& 
Kaźmierczak, 2011). Probably, the best 'living' analogues for Precambrian stromatolites are found in alkaline crater lakes in Tonga (Kaźmierczak \& Kempe, 2006; Kremer et al., 2012). These domical laminated deposits grow through the calcification and silicification of cyanobacterial mats, resulting in crystalline laminated fibrous fabrics rather than grainy fabrics.

This study presents newly discovered Pleistocene fibrous laminated and non-laminated aragonite crusts and spherulites that occur in two transitional phases from open marine (Red Sea) to hypersaline conditions in the Danakil Depression (Afar, Ethiopia). These Quaternary fibrous non-laminated crusts and stromatolites (following the definition of Semikhatov et al., 1979) closely resemble fibrous sea-floor crusts and stromatolites from the Precambrian and Palaeozoic record. Their mineralogical and petrographic characteristics are described and discussed regarding their mode of microbially mediated and/or abiotic formation as well as other controlling factors, such as type of substrate and depth of formation.

The study of the crusts and stromatolites in Afar offers a great opportunity to better understand primary fabrics prior to major diagenetic transformations, giving insights into their primary mineralogical composition, their mode of precipitation and their dependency on external environmental parameters.

\section{GEOLOGICAL SETTING}

The Danakil Depression, situated in the northern part of the Afar triple junction (up to $120 \mathrm{~m}$ below sea level), is part of an active rift associated with the break-up of the Afro-Arabian plateau (Fig. 1A and B). It is believed that the early stage of rifting between Arabia and Africa was initiated by the eruption of the Ethiopian trap series around $30 \mathrm{Ma}$ (Baker et al., 1972; Hofmann et al., 1997). After this initial phase of break-up along the East African Rift and Red Sea system, the Gulf of Aden rift propagated from the Indian Ocean towards the Afar Depression (Manighetti et al., 1997).

The Danakil Depression is bordered to the west by the Ethiopian Plateau and to the east by the Danakil Horst (Fig. 1A and B). This depression represents the southern prolongation of the Red Sea Rift, evidenced by high-density GPS data showing that south of $\mathrm{ca} 16^{\circ} \mathrm{N}$ the rift bifurcates into two branches; the Red Sea and the subaerial Danakil Depression (ArRajehi et al., 2010; McClusky et al., 2010; Keir et al., 2013). The crust below Afar is considered to be variably stretched, and is intruded continental crust and not yet oceanic crust (Makris \& Ginzburg, 1987; Keir et al., 2013). The thinnest crust in Afar is found in the Danakil Depression, northward of $13^{\circ} \mathrm{N}$ where it thins from 20 to $25 \mathrm{~km}$ in the south to around $15 \mathrm{~km}$ in the north (Makris \& Ginzburg, 1987; Hammond et al., 2011), suggesting that this depression represents the locus of the onset of sea-floor spreading in Afar. The central-southern part of the depression hosts the Erta Ale volcanic range composed of a series of shield volcanoes ( $<1$ Ma; Fig. 1B; Varet \& Gasse, 1978). Cenozoic syn-rift sediments lie discordantly on Mesozoic rocks and are laterally interfingered with the Afar basalts (Neogene) and the Aden volcanic deposits (Quaternary; Fig. 2). The sedimentary fill in the central-northern part of the depression is characterized by an evaporitic succession with a total thickness of more than $900 \mathrm{~m}$ (Hutchinson \& Engels, 1970; Brinckmann \& Kürsten, 1971). These evaporites are mainly composed of halite intercalated with gypsum, anhydrite and economically significant potash, which were widely studied in the 1960s and 1970s (Holwerda \& Hutchinson, 1968; Bannert et al., 1971). The age of this evaporitic succession is still uncertain.

Marine deposition at the basin margins is controlled by the interaction between tectonics and eustatic sea-level changes that led to several episodes of marine invasion of the basin during the Pleistocene (Atnafu et al., 2015). These episodes of marine flooding followed by desiccation resulted in the deposition of diverse facies, from normal-marine coralgal reefs to oolite shoals and beaches, to gypsum. These deposits were attributed to the Zariga Formation (Brinckmann \& Kürsten, 1971; Fig. 2) which surrounds the entire Danakil Depression (Figs 1, 3A and 3B). Lalou et al. (1970) performed U/Th dating on corals and Tridacna shells of seven outcrops located around the depression, and attributed ages between $200 \mathrm{kyr}$ and $80 \mathrm{kyr}$ for the deposition of the coralgal reefs. These authors concluded that probably two episodes of coral terrace formation took place within the depression, ca $200 \mathrm{kyr}$ and ca $80 \mathrm{kyr}$, respectively. In this study, two different sedimentary units separated by a marked erosion surface have been recognized at each studied locality. They have been informally named Lower and Upper successions (see below). These deposits crop out as terraces, 

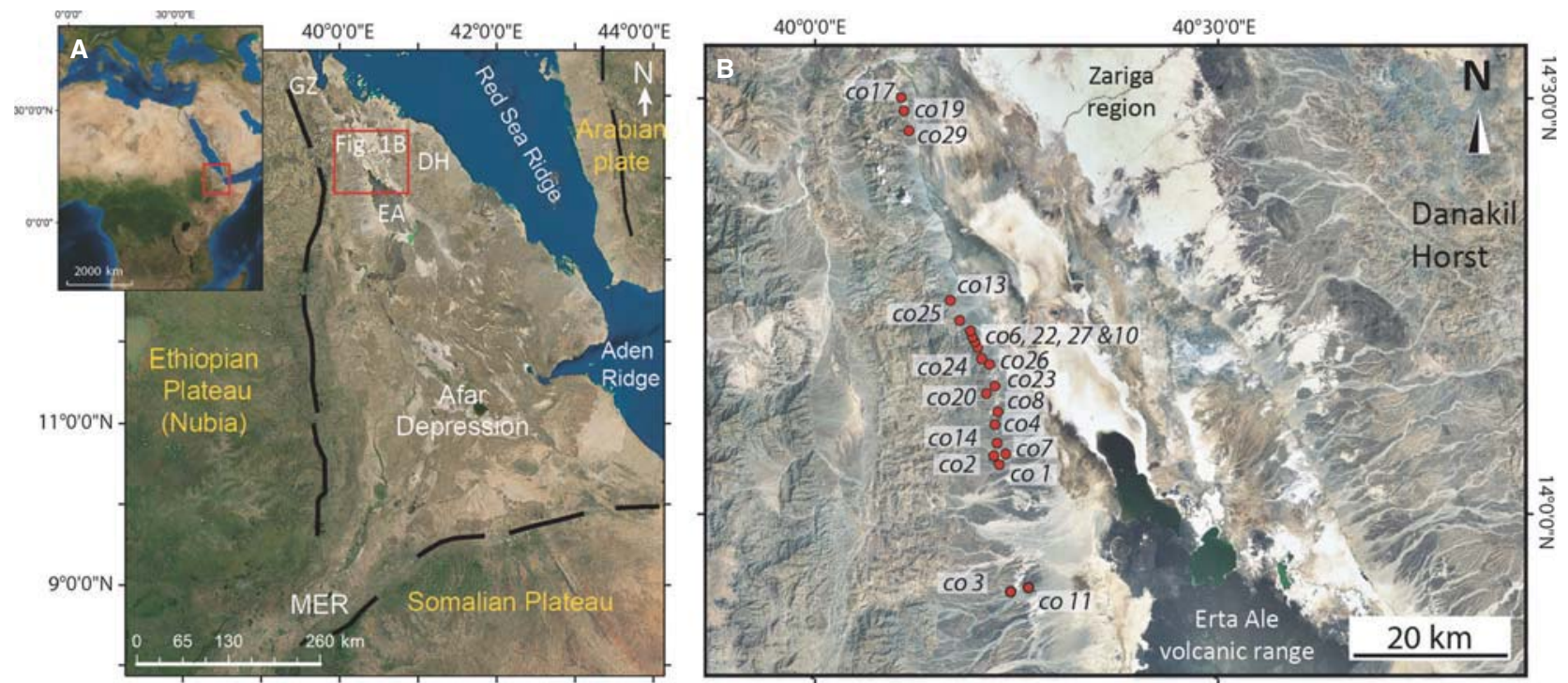

Fig. 1. (A) Satellite image of the Afar Depression (NASA Landsat 7 Program, 2003, Landsat ETM+) showing the location of the Main Ethiopian Rift (MER), the Red Sea Ridge and the Aden Ridge. The red square indicates the area of interest. Black lines are Oligo-Miocene border faults (Keir et al., 2013; GZ = Gulf of Zula; DH = Danakil Horst; EA = Erta Ale volcanic range). (B) Satellite image showing locations of the studied outcrops (red dots) along the fossil fringing reefs exposed at the Ethiopian side of the Danakil Depression.

whose relative elevation depends on local tectonics. Poorly preserved, potentially older terraces occur at a few sites. The main connection to the Red Sea during the Pleistocene is believed to have been through the Gulf of Zula (Fig. 1A), and to have been posteriorly closed by uplift associated to the doming of the Alid volcano (Lalou et al., 1970; Bonatti et al., 1971).

\section{MATERIALS AND METHODS}

With yearly average temperatures of $36^{\circ} \mathrm{C}$, the Danakil Depression is one of the hottest places on Earth. Because of its climate, the depression is free of vegetation and therefore exhibits ideal exposure conditions. Despite its geological importance, the Danakil Depression has long been inaccessible to geologists for political reasons (Barberi \& Varet, 1970). During four field expeditions (between October 2013 and February 2017), 29 outcrops spread over a distance of $70 \mathrm{~km}$ on the western margin of the depression were studied. Besides marine deposits (ooid and bioclastic grainstones as well as coralgal reefs), 21 of these outcrops contain crusts and/or spherules composed of fibrous aragonite (Table 1; Fig. 1B). In total, 245 samples, including 90 samples of the fibrous facies, were collected. All rock samples were cut into slabs, on which the position for thin sections were indicated. Slabs were scanned with an optical scanner prior to thin section preparation. Fabric analyses were performed on slabs and on polished thin sections by means of petrographic microscopy. The description of fabrics follows the worksheet for stromatolite field studies proposed in the Handbook for the Study of Stromatolites and Associated Structures (Grey, 1989). UltraViolet excitation for fluorescence microscopy was induced by a $\mathrm{Hg}$ vapour lamp attached to a Leica DMRXP microscope equipped with a Leica EL6000 (bandpass filter BP 340 to $380 \mathrm{~nm}$ for blue light; Leica, Wetzlar, Germany).

Data on site elevation was obtained with a differential GPS (relative to ground control points made available by Allana Potash mining company) and/or a handheld GPS ( $\pm 5 \mathrm{~m})$. The large spread of elevations between the different outcrops (see Table 1) is due to differential regional uplift or subsidence of blocks along the depression margin. Therefore, absolute values cannot be used for depth reconstruction. The depth of formation of crusts was calculated from the difference between the elevation of the crust site and the elevation of the shallowest deposits; i.e. coralgal-reef top or beach sediments (with crusts) of the same outcrop/locality, which are interpreted to correspond to palaeo-sea-level. In some outcrops, it is possible to laterally follow sediment units connecting shallow and deeper 


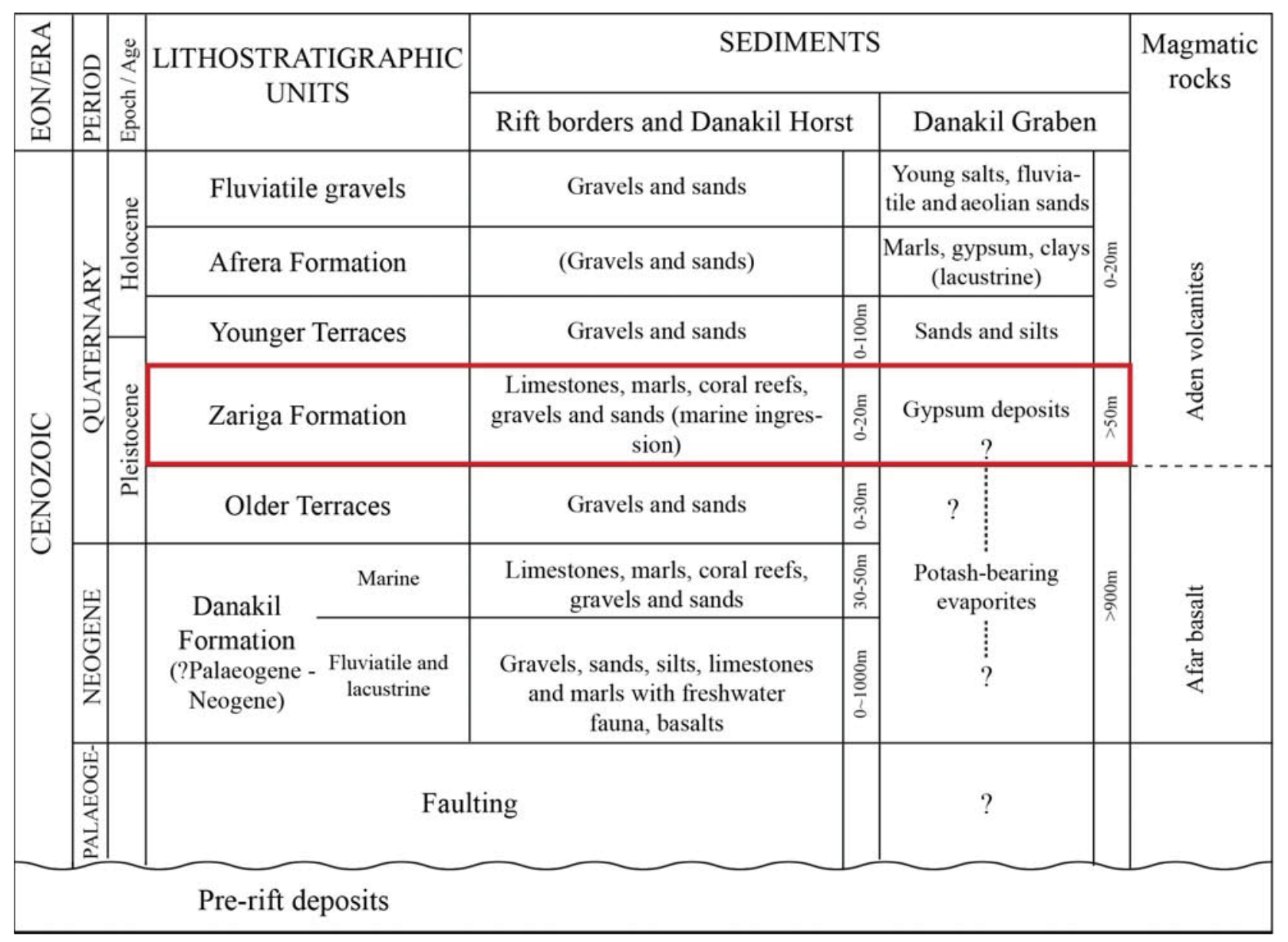

Fig. 2. Lithostratigraphy of the Danakil Depression showing the stratigraphic context of the marine deposits of the Zariga Formation (red rectangle; modified after Brinckmann \& Kürsten, 1971).

parts, with no evidence of faulting. Therefore, within the same succession and at small outcrop scale, faults can be excluded as the cause for elevation differences.

Powder samples for mineralogical analyses were extracted with a hand-held microdrill. Mineralogy was determined by X-ray diffractometry (XRD) at the Department of Geosciences, University of Fribourg, Switzerland, using a Rigaku Ultima IV diffractometer equipped with D/teX detector (Rigaku Corporation, Tokyo, Japan) and a $\mathrm{Cu}$ X-ray tube operated at $40 \mathrm{kV}$ and $40 \mathrm{~mA}$. Additionally, bulk samples of crusts of the Upper succession (see below) were milled and the powder treated with $0.2 \mathrm{M}$ acetic acid to eliminate most of the carbonate phases prior to XRD analyses of the clay mineralogy. The diffractograms were recorded in continuous mode from $2 \theta$ angles $4 \cdot 25^{\circ}$ to $80 \cdot 0^{\circ}$ with a speed of $1^{\circ} 2 \theta \mathrm{min}^{-1}$. The diffractograms have been analysed with the PDXL 2 software package from Rigaku using the ICDD PDF-4+ data base. The unit cells of the phases were refined with the Rietveld code integrated in the Rigaku PDXL 2 software package.

A few milligrams of crust material containing Mg-silicates were gently crushed in a mortar. Isopropanol was added, and a drop of the suspension deposited on a carbon-coated copper grid. The sample was subsequently analysed by transmission electron microscopy (TEM) with a JEOL 2100 (JEOL Limited, Tokyo, Japan) at the Swiss National Accident Insurance Fund (SUVA, Lucerne, Switzerland) equipped with an energy-dispersive spectrometry (EDS) system to obtain chemical analyses. The microscope was operated at $200 \mathrm{kV}$.

The microfabrics of distinctive facies were visualized with the in-house scanning electron microscope FEI XL30 Sirion FEG (Thermo Fisher Scientific, Waltham, MA, USA) in the Department of Geosciences, University of Fribourg, 
A

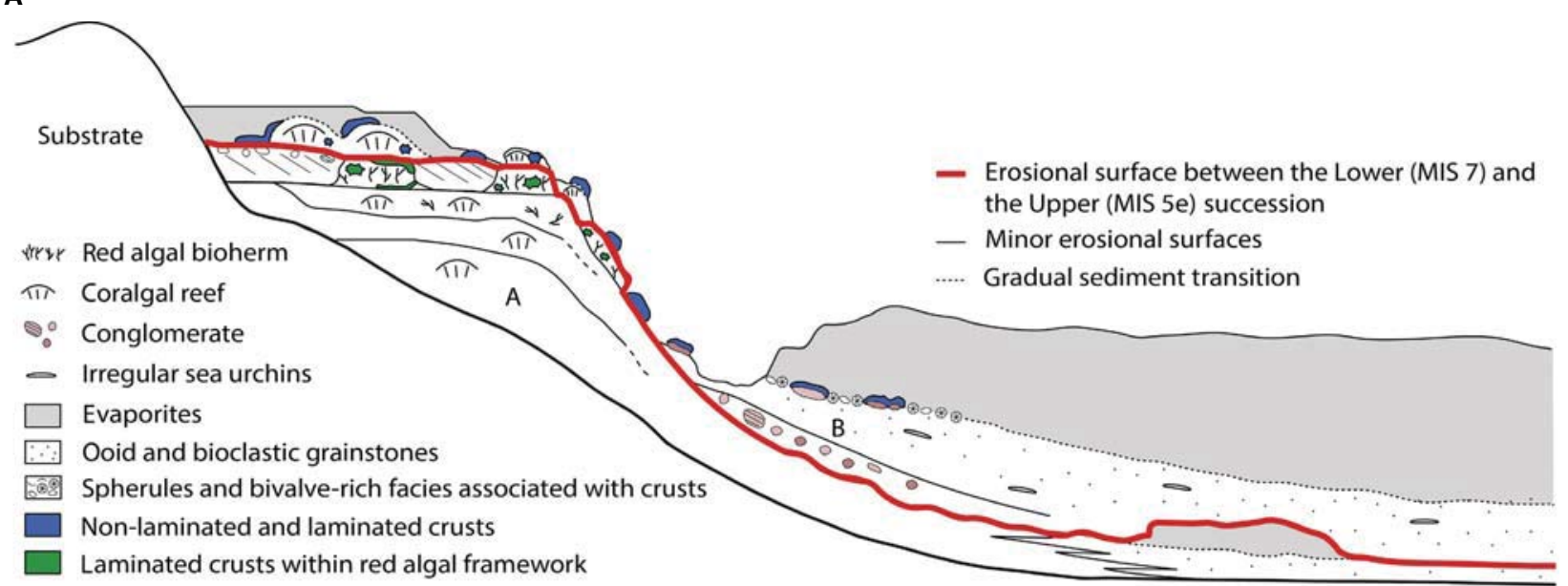

Not to scale
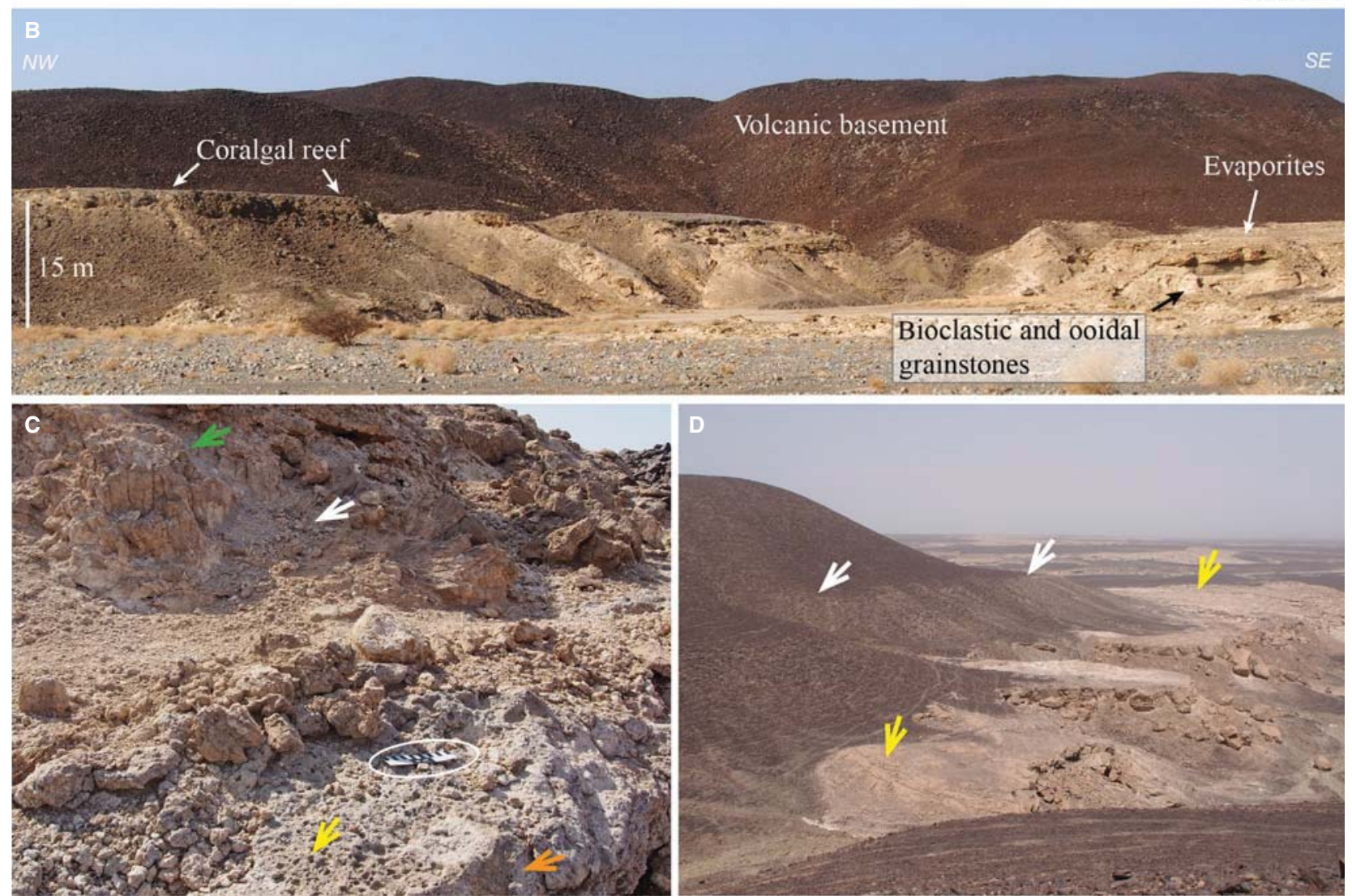

Fig. 3. (A) Schematic stratigraphy of the marine terraces showing the relation between the Lower ' $A$ ' and the Upper 'B' successions, as well as the stratigraphic position of the different fibrous aragonite crusts. (B) Panorama picture of outcrop CO2 showing the Pleistocene fringing reef units attached to the volcanic substrate (left), the bioclastic and ooidal grainstones, as well as the evaporite deposits overlaying the marine succession. (C) Close-up of the transition between the Lower and the Upper succession. Note the stronger lithification of the Lower succession (orange arrow) compared to the Upper succession (white arrow). The erosion surface between the two successions is bioeroded by Gastrochaenolites borings (yellow arrow; CO1 outcrop). A coral colony in living position formed in the Upper succession is pointed to with a green arrow. The ruler (white ellipse) is $15 \mathrm{~cm}$ long. (D) Panoramic view of outcrop CO4, where it is possible to see the difference in elevation of the Lower succession (white arrows) and the Upper succession (yellow arrows), caused by local uplift. MIS = Marine Isotope Stage. 


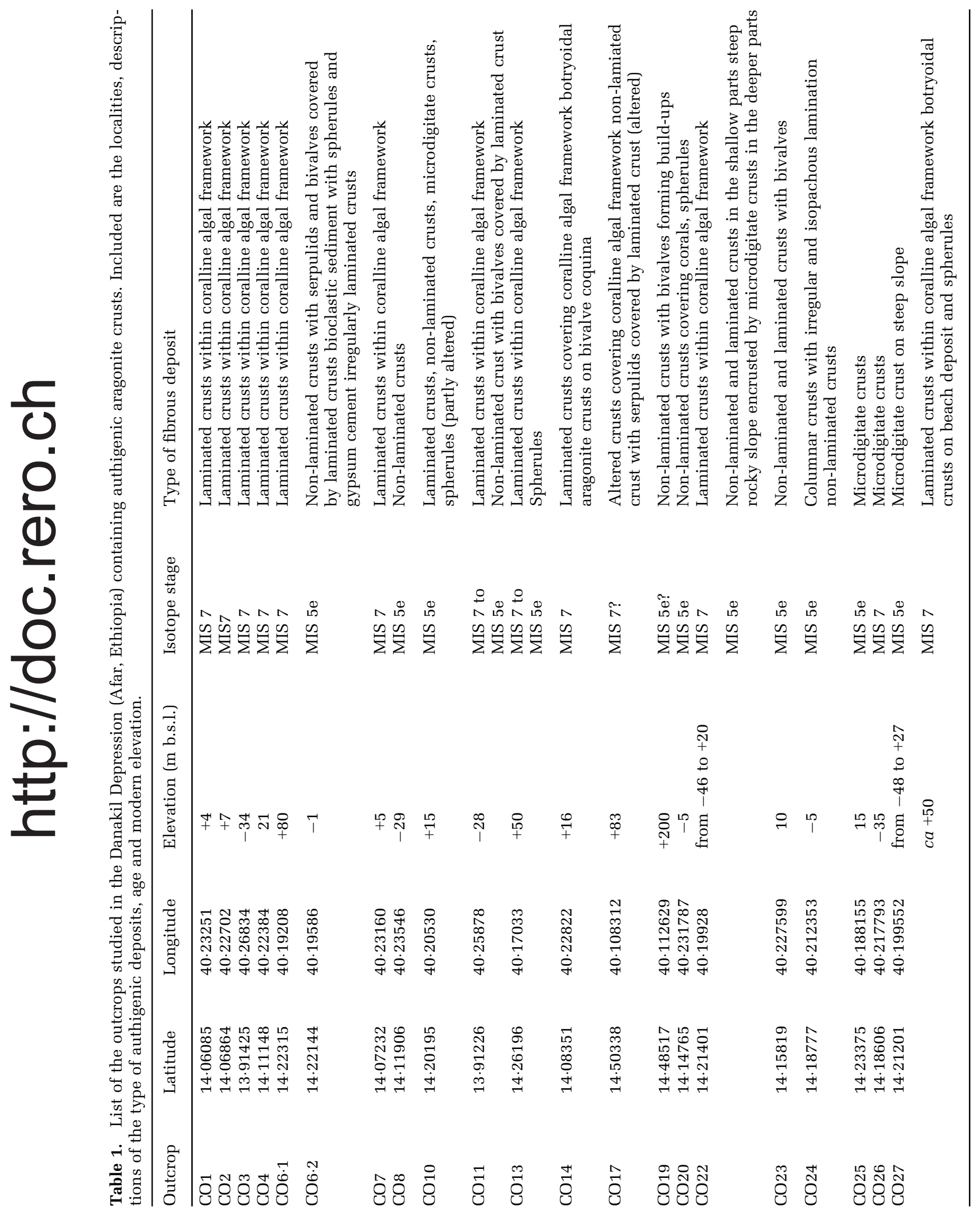


Switzerland. This microscope is equipped with an EDAX NEW-XL30 EDS detector (FEI Compant, Hillsboro, OR, USA). This technique was also used to produce element maps of several thin sections $(25 \mathrm{keV}, 1.2 \mathrm{nA}$, dwell time $50 \mathrm{~ms}$ per pixel, $5 \mu \mathrm{m}$ spot size).

Uranium/thorium (U/Th) dating of the younger unit was performed on two coral samples. Due to the lack of well-preserved corals in the older unit, dating was performed on two thick Tridacna shells. Samples were purified following the chemical procedures of Cheng et al. (2000). The U/Th dates were measured at the GEOMAR Helmholtz-Zentrum für Ozeanforschung Kiel (Germany) mass spectrometry facilities with a Finnigan MAT $262 \mathrm{RPQ}^{+}$multicollector mass spectrometer (Thermo Fisher Scientific).

The stable carbon-isotope and oxygen-isotope composition of 59 micro-drilled powder samples of primary aragonite was measured using a Finnigan MAT Delta Plus XL mass spectrometer equipped with an automated GasBench II (Thermo Fisher Scientific) at the Institute of Mineralogy and Geochemistry of the University of Lausanne (Switzerland). All results are reported in \%o relative to the Vienna Pee-Dee Belemnite (VPDB) standard. The analytical reproducibility for three runs was $\pm 0.09 \%$ for both $\delta^{13} \mathrm{C}$ and $\delta^{18} \mathrm{O}$.

\section{RESULTS}

\section{Stratigraphic framework}

At each studied locality there are at least two different sedimentary units (Lower and Upper successions) forming two marine terraces, which are separated by a marked erosion surface (Fig. 3A). The stratigraphically underlying unit has stronger lithification and shows vast polished surfaces on eroded lithified grainstones and packstones, and deep incisions on coral frameworks. These surfaces are often bioeroded (Gastrochaenolites) and colonized by coral colonies in living position belonging to the overlying unit (Fig. 3C). Additionally, preservation of aragonite constituents is poor in the lower unit, with almost all aragonite converted to neomorphic calcite, while the younger succession still preserves aragonite components.

Uranium/thorium dating of the younger unit performed (Upper succession) on two corals yielded ages between $121.9 \mathrm{kyr}$ and $122.9 \mathrm{kyr}$ (Table 2). Taking into account the partial opensystem behaviour, data can be assigned to Marine

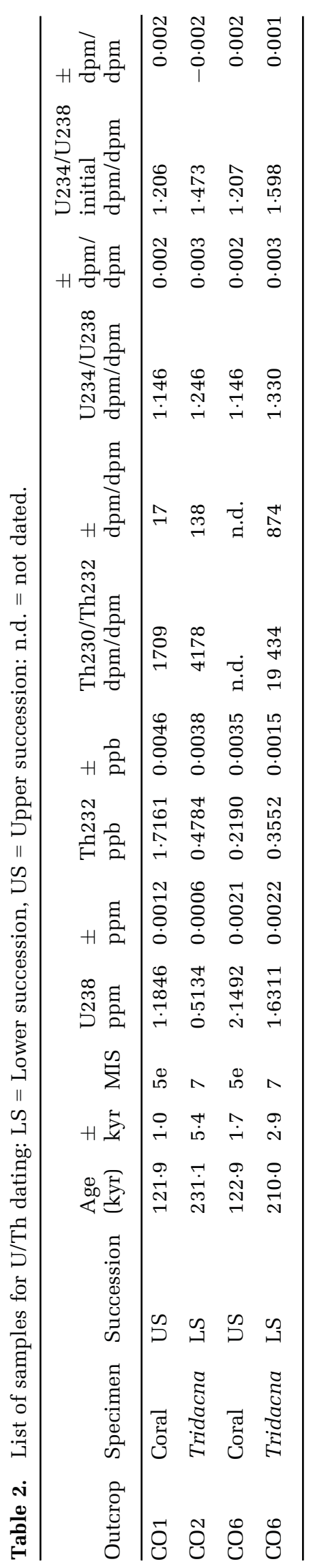


Isotope Stage 5 (MIS 5), probably MIS 5e. The U/Th dating of the older succession (Lower succession) was more difficult as no well-preserved corals were available. Analyses performed on two thick Tridacna shells gave ages of $231.1 \mathrm{kyr}$ and $210.0 \mathrm{kyr}$. Even though there can be a large uncertainty in U/Th dating performed on Tridacna shells (Ayling et al., 2017), it is still reasonable to assign this unit to MIS 7. This fits well with the stratigraphic position of the unit and the strong difference in diagenesis and lithification between the two successions. These results are in agreement with two of the three ages postulated for marine deposits by Lalou et al. (1970). This means that during the Pleistocene at least two marine incursions took place, during MIS 7 and MIS 5, respectively.

The spatial relationship between these two units depends largely on local tectonic development. Local uplift implies that in some places the older terrace occurs higher than the younger reef units (Fig. 3D). This situation is more often found in the northern part of the Danakil Depression. In the central and the southern part of the depression, elevation differences are typically less pronounced. In these outcrops, the younger unit forms a thin layer overlying the older coralgal reef unit (Fig. 3C).

\section{Stratigraphic position and growth-forms of aragonite crusts}

Aragonite crusts occur at two specific positions within the Pleistocene marine to evaporitic succession of the Zariga Formation. These rocks are found: (i) encrusting the uppermost marine deposits of the Lower succession (MIS 7); and (ii) at the transition between marine and evaporitic deposits in the upper part of the Upper succession (MIS 5; Fig. 3A). It is possible to observe differences in crust morphology and microfabrics following changes in elevation and substrate type along proximal to distal palaeodepth profiles of the better exposed MIS 5.

\section{Lower succession}

The Lower succession comprises a fringing reef characterized by a rich normal marine fauna dominated by corals and red algae. Reef bodies are made of prograding units separated in their shallow parts by erosional surfaces of unknown significance. Micritic marine crusts are found within voids in the coral framework. The upper part of the Lower succession is characterized by an up to $2 \mathrm{~m}$ thick red algal framestone (patches and biostromes; Fig. 4A) mainly made of branching (fruticose) and laminar Lithophyllum gr. kotschyanum with minor Lithophyllum gr. prototypum, Lithophyllum gr. pustulatum and Porolithon onkodes. This strongly lithified framework can be found at the top of the reef flat and upper slope in almost all of the studied coralgal reef outcrops corresponding to MIS 7. The algal frameworks are a prominent feature that formed at the end of this stage, before the deposition of gypsum beds. These frameworks are laterally interfingered with coquinas composed of the bivalve Brachidontes pharaonis and gastropods, as well as oolites. Former voids between coralline algal branches and in bivalve coquinas are typically filled with botryoidal aragonite cements.

Larger voids within the framework are filled with aragonite crusts (up to $30 \mathrm{~cm}$ thick; Fig. 4B to E). These crusts form laminated mammillary and columnar (Fig. 4C and D) upward-growing structures that encrust the bottom or sides of the cavities, while thinner non-laminated crusts locally cover the roofs (Fig. 4C).

Lamination can best be recognized on weathered surfaces (Fig. 4D). Deposition of aragonite crusts is followed by extensive dissolution and the formation of a late diagenetic rim of isopachous blocky calcite cement. Sediments below and above the coralline algal-dominated bed are neither affected by the formation of crusts, nor by the formation of extensive botryoidal cements. In a few outcrops, were the gypsum covering MIS 7 deposits is still preserved, a red algal dominated grainstone ( $>2 \mathrm{~m}$ thick) laterally interfingers with the coralgal reef. This algal grainstone is covered by a fine-grained ooid rich bioclastic grainstone $(10 \mathrm{~cm}$ thick) that gradually passes into a coarser grained (ooids $>2 \mathrm{~mm}$ ), cross-bedded, oolitic grainstone rich in lithoclasts (60 $\mathrm{cm}$ thick), containing spherules. Within the oolite bed, there is a gradual increase in spherules towards the top, where spherules dominate. Some of the spherules are covered by a calcitic coat resembling that of the ooids. This succession is covered by evaporites.

\section{Upper succession}

The marine deposits of the Upper succession are characterized by isolated coral frameworks that do not form an extensive reef, such as in the Lower succession. It is also notable that red algae play a minor role in comparison to the succession below. Micritic crusts, probably microbial in origin, are found locally between 

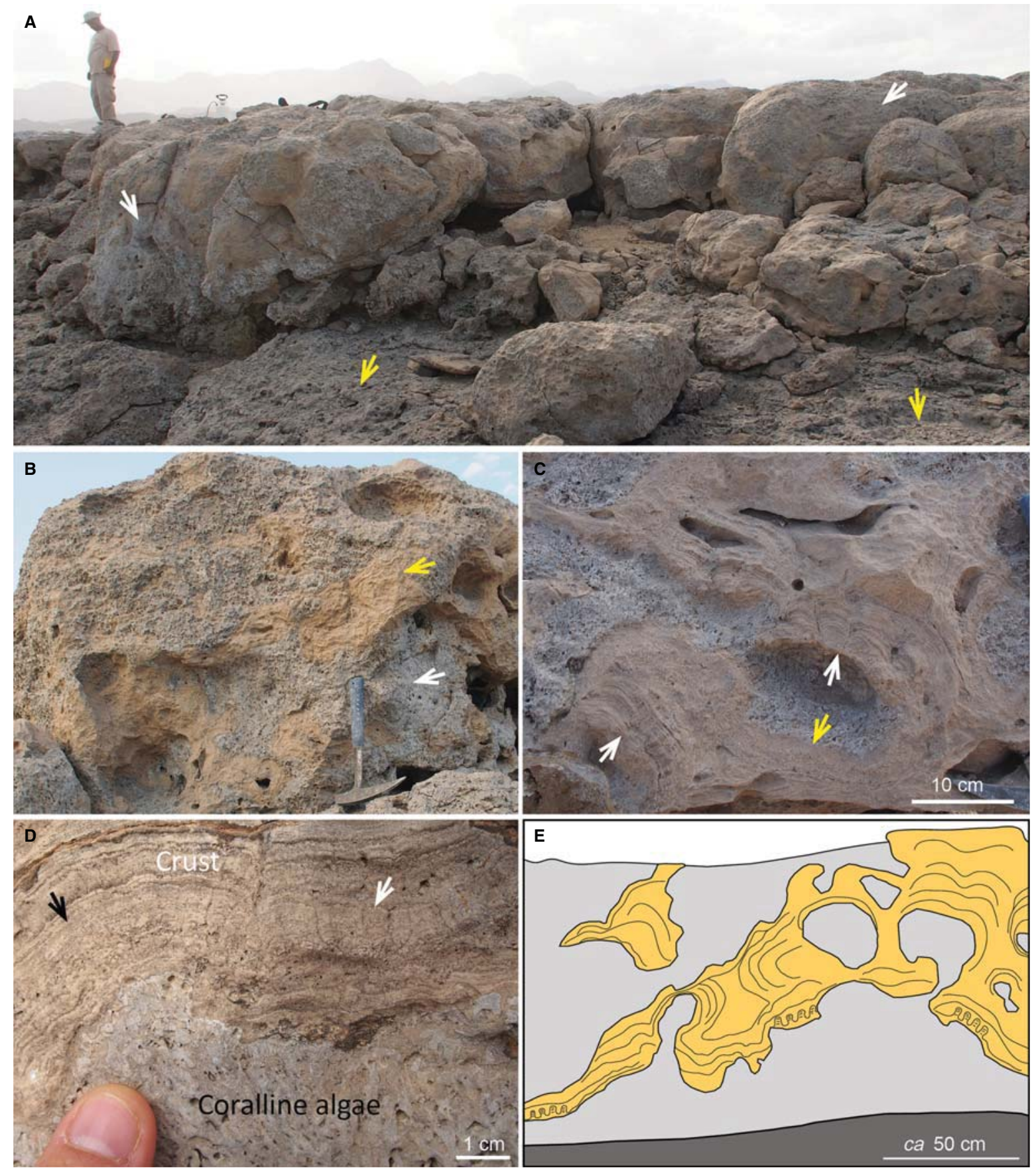

Fig. 4. Predominantly isopachously laminated crusts found in the upper part of the Lower succession (CO14 outcrop). (A) Field picture of a red algal framework. Note the lateral extension of coralline algal biostrome (white arrows) covering coralgal reef deposits (yellow arrows). The person to the left of the image is $1.7 \mathrm{~m}$ tall. (B) Detail of coralline framework (greyish colour, white arrow) with wide (up to $30 \mathrm{~cm}$ ) irregularly distributed former voids filled with aragonite crusts (yellow arrow). Hammer for scale is $33 \mathrm{~cm}$ long. (C) Asymmetrical growth of the authigenic infill. Note thicker laminated columnar and flat crusts (white arrows) growing upward from the algal substrate, while, thinner and predominantly non-laminated crusts (yellow arrow) grew downward from the void roofs. (D) Detail of isopachously laminated crusts. Note the presence of two different types of crust growth-forms in the same layer. The central part is characterized by columnar growth (white arrow), whereas to the left, a flat laminated crust is developed (black arrow). (E) Schematic representation of the relation between the red algal framework (grey) and the laminated authigenic aragonite crusts (yellow) at outcrop scale. Note that although crusts are internally isopachously laminated, they do not form isopachous infills, instead there is a tendency to form thicker crusts at the base or sides of cavities, where columnar and flat laminated growth-forms coexist. 

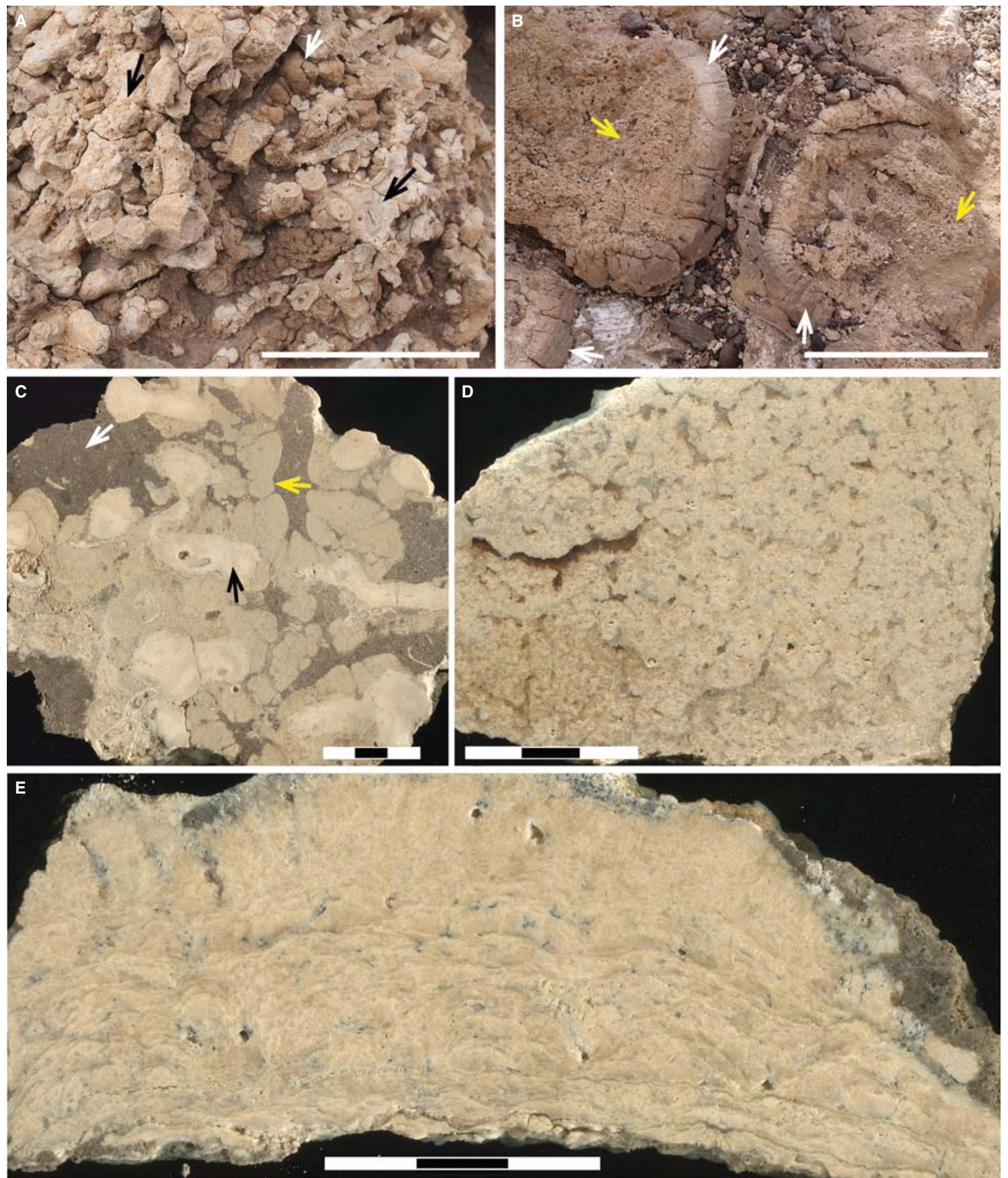

Fig. 5. Field pictures and scans of rock slabs showing authigenic crusts formed in shallow environments in the Upper succession. (A) Coral framework in growth position (black arrows) encrusted by fibrous aragonite cements (white arrow; CO6 outcrop). Scale $=10 \mathrm{~cm}$. (B) Shallow crust domes displaying a complete succession from an inner non-laminated crust (yellow arrows) to a laminated columnar crust (white arrows; CO27 outcrop). Scale $=30 \mathrm{~cm}$. (C) Slab scan of the coral framework shown in (A). The coral (black arrow) is covered by a non-laminated crust at the base and a laminated crust at the top (yellow arrow). Remaining space within the framework is filled with brown bioclastic rich sediment (white arrow). (D) Non-laminated aragonite crust with 'thrombolitic-like' appearance (CO19 outcrop). (E) Crust showing flat irregular lamination in the lower part gradually passing to shrubs in the upper part (CO24 outcrop). Scale $=3 \mathrm{~cm}$. 
coral branches and growing directly on the steep bare surface of the basement in deeper parts (tens of metres of water depth). In the upper part of the succession, which corresponds to MIS 5, marine facies are directly covered by fibrous aragonite crusts and build-ups. The crusts are overlain by evaporites; they are always found on hard substrates, which can consist of large bioclasts (corals or bivalves), boulders or the basement. No crusts were observed on mobile substrates.

Framework porosity within corals and, to a lesser extent, coralline algae (fruticose Lithophyllum gr. kotschyanum with minor Porolithon onkodes) can be partly filled by crusts (Fig. 5A and $\mathrm{C}$ ). Outside the marine framework, crusts commonly occur as small domes (a few centimetres to $1 \mathrm{~m}$; Fig. 5B) with an inner, mainly nonlaminated shrubby or fibrous 'thrombolitic' (Fig. 5D) fabric, sometimes displaying areas with irregular lamination (Fig. 5E), associated with small chamid bivalves and serpulids. These sessile organisms are typically found embedded in the crust, and in some cases provide an important volumetric contribution to their construction. The bivalve and serpulid-rich basal part of the crust is often covered by a columnar or noncolumnar laminated interval (up to $10 \mathrm{~cm}$ in thickness; Figs 5B and 6A). Lamination within columns is flat to convex. Columns may be coalesced non-branching (Fig. 6A), as well as parallel branching (Fig. 6B) with a scutate to polygonal plan outline and erect to recumbent morphologies. Columns may be closely spaced (Fig. 6B) or separated by sediment (Fig. 6C) and have a diameter of up to $6 \mathrm{~cm}$. Space between columns is filled with oolitic or peloidal sediment with or without Mg-silicates.

Crusts were found along the dipping substrate at vertical elevations equivalent to up to $80 \mathrm{~m}$ lower than the elevation of the coral reefs, red algal framestones and beaches of the same unit. These crusts mainly occur on relatively steep $\left(>30^{\circ}\right)$ slopes. Depending on the availability of hard substrate, they are found as isolated buildups (for example, on rubble; Fig. 7A and B) or covering extensive areas of tens of square metres directly on the basement (Fig. 7C). These crusts even appear on vertical and overhanging walls reaching a maximum thickness of $20 \mathrm{~cm}$. Crusts are dominated by shrubby and columnar microdigitate fabrics (Fig. 7D and E). Microdigitate columns nucleate and radiate from isolated nucleation points (Fig. 7F). The crusts grow perpendicular to the substrate and do not show any upward polarity. Columnar microdigitate fabrics of the deeper crusts rarely show bifurcations. Neither bivalves nor serpulids are present within these crusts and isopachously laminated fabrics are dominant. The single digits display a convex lamination, responding to their radial fibrous nature. The outer surface of the crust shows a brain-like irregular appearance (Fig. 7B).

Spherulites are laterally interfingered with the crusts. They make a thin $(<10 \mathrm{~cm})$, discontinuous layer rich in spherules, that forms exclusively on top of ooid or bioclastic grainstones or packstones rich in fragments of the sea urchin Laganum depressum. The layer typically occurs in more distal positions where hard substrate is scarcer. The lower and upper boundaries of the layer show no sign of an interruption in sedimentation. Spherules are embedded in a grain-supported sediment (Fig. 6E) rich in faecal pellets, unidentified peloids, ooids and bioclasts. The matrix, when present, is made of soft whitish carbonate mud. The bioclasts are mainly bivalves, gastropods and serpulids, but benthic foraminifera debris and coralline algae debris also occur. Among the molluscs, accumulations of the bivalve Brachidontes pharaonis, and the potamidid Pirenella conica are most common. Brachidontes pharaonis is found forming accumulations of disarticulated valves in crosslaminated beds, as well as clusters of articulated shells (Fig. 6E). If boulders or large bioclasts are present in the layer, they can be covered by a crust.

Intraskeletal pores in bivalves and gastropods are often filled with fibrous aragonite cement (Fig. 6F). A later generation of cements is characterized by large gypsum crystals filling interstitial pores and remaining pore spaces within bioclasts.

\section{Microfabrics and mineralogy}

Euhedral aragonite fibres, with varying degrees of replacement by calcite, are the main components of the authigenic fabrics described above (Fig. 8A). The fibres can reach up to $15 \mu \mathrm{m}$ in diameter, with a length of a few millimetres. The most common arrangement of aragonite fibres is in radial fans that can form individual or coalescent mamelons showing sweeping extinction under cross-polars. In this study, a distinction between botryoids containing tangentially oriented internal lamination, or growth lines (Figs 8B and 9A.1) and fans devoid of lamination (Figs 8C and 9B.1) is made. Botryoids containing lamination are comparable to those described by Ginsburg \& James (1976), Aissaoui 

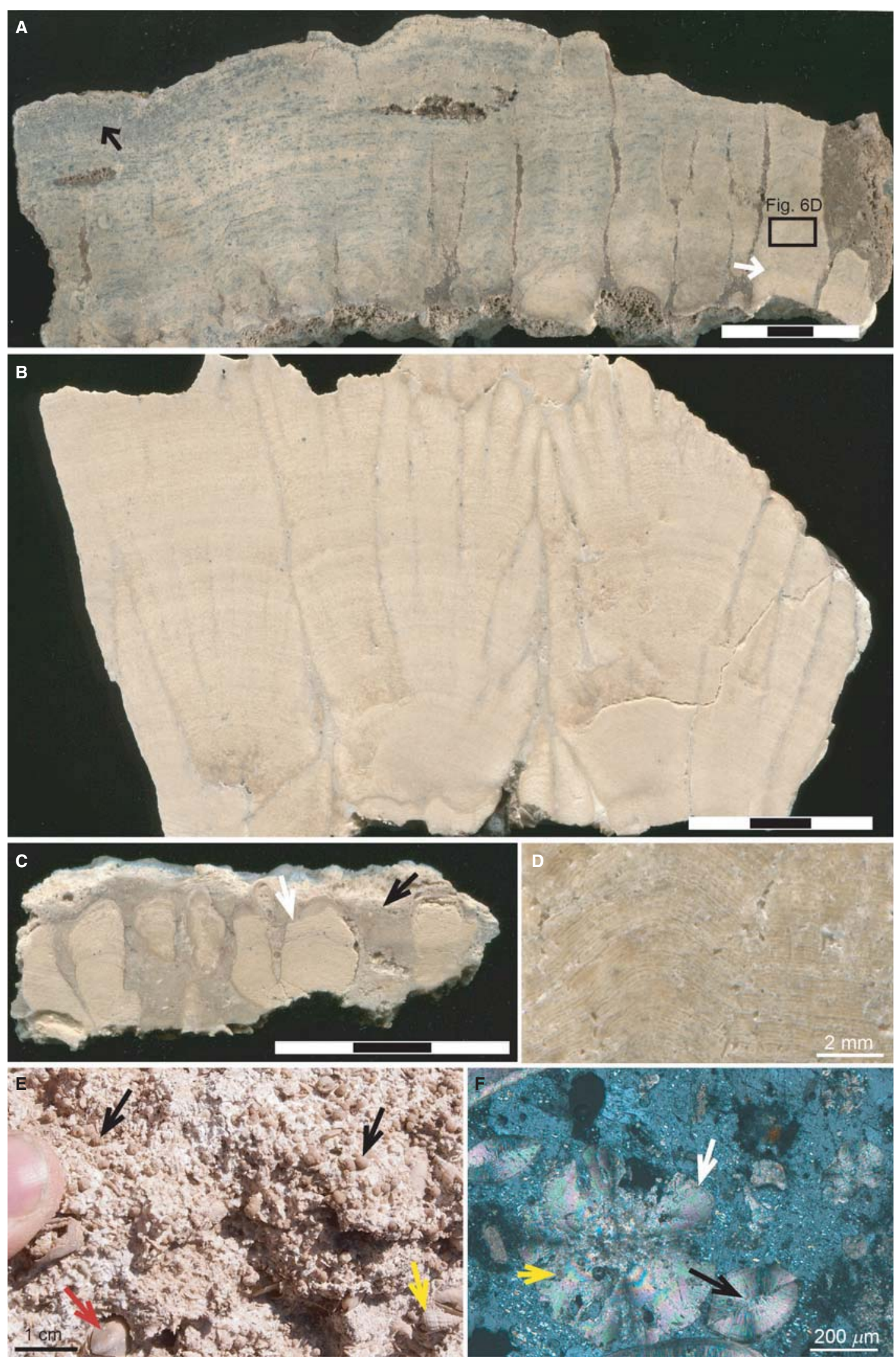
Fig. 6. Slabs of shallow columnar crusts of the Upper succession (A) to (D). (A) Laminated crust from the upper part of the domes in Fig. 5B, showing a lateral transition from flat laminated (left) to laminated non-branching columnar fabric (right). A dark diagenetic phase (black arrow) advanced from the upper left to the right side of the image. The white arrow shows a well-preserved part of a column with isopachous lamination (see Figs 6D and 8D; CO22 outcrop). (B) Crust with closely spaced parallel branching (bifurcating and trifurcating) laminated columns (CO24 outcrop). (C) Columns (white arrow) completely surrounded by embedding sediment (black arrow). Scale for (A) to (C) $=3 \mathrm{~cm}$. (D) Close-up of the crust shown in (A) displaying flat (right) and convex-up (left) isopachous lamination made by alternation of aragonite (darker) and porous Mg-silicate rich (brighter) laminae. (E) Close-up of sediment laterally interfingered with crusts in the Upper succession. Note the brownish aragonite spherules weathered out of the rock (black arrows; CO6 outcrop). A specific bivalve assemblage dominated by Brachidontes pharaonis (red arrow) and potamidid gastropods (yellow arrow) occurs in this rock. Brachidontes pharaonis is often found with both valves articulated. (F) Photomicrograph of a thin section of a grain-supported sediment containing spherules (white arrow). Large pores and Mg-silicate inclusions (yellow arrow, brown inclusion) in the spherule give it a 'dirty' appearance. Black arrow points to a bivalve filled with clean aragonite fibrous cement. The cement between the particles is made of large gypsum crystals that appear grey under cross-polars.

(1985) and Brachert et al. (2007). Within both botryoids and fans, crystals increase in width along their length axis (Fig. 8A).

\section{Isopachous lamination}

Isopachous lamination is found as flat to pseudocolumnar, laterally continuous lamination, as well as laterally confined lamination within non-branching and branching columns (Fig. 8D), and microdigitate crusts. This lamination is characterized by laterally constant thickness at millimetre to centimetre-scale (Fig. 6D). Single laminae are typically between $50 \mu \mathrm{m}$ and $500 \mu$ m thick but can reach up to a few millimetres. Light laminae (dark in thin section) are generally thinner, having a thickness in the order of a few micrometres. Flat-laminated isopachous crusts nucleate as separate botryoids (Figs 8B and 9A.1). Where botryoids coalesce, only the central part of the aragonite fibres persists, and lamination is continuous between adjacent botryoids (Fig. 9A.2). Isopachously laminated digits and columns start from distinct nucleation points and grow radially until adjacent botryoids are met; then they grow in a single direction, forming individual radial fibrous digits and columns (Fig. 9A.3).

At the micro-scale, some differences exist between the isopachous laminations within the crusts and botryoids from the Lower succession and the columnar and flat-laminated crusts of the Upper succession. The few pristine examples of isopachous lamination in the Lower succession show no compositional or elemental variations throughout the laminae, neither in backscatter images nor in EDS maps. Aragonite fibres are not interrupted at lamination planes and lamination is only visible under transmitted light. Benzerara et al. (2010) observed a comparable type of banding in laminated rocks found in the Satonda Crater Lake (Indonesia), but the cause for this type of lamination is not fully resolved. In the Upper succession, SEM-EDX spectra reveal the presence of Mg-silicate and gypsum associated with lamination. Lamination can be caused either by alternation of aragonite and Mg-silicate laminae (Figs 8D and 9A.3), or continuous aragonite fibres displaying zones that contain filamentous Mg-silicate inclusions $(<10 \mu \mathrm{m}$; Fig. $8 \mathrm{~F})$ and/or microporous intervals (pores smaller than a few microns), that are oriented tangentially to the growth direction.

Isopachously laminated crusts locally contain trapped bioclasts or siliciclastic grains. In some cases, surfaces of interruption or dissolution are found. These surfaces can be covered by Mgsilicate drapes (Fig. 8E).

\section{Irregular or discontinuous lamination}

Irregular lamination is only found within crusts of the Upper succession (Fig. 5E). This lamination is produced by the alternation of laminae composed of coalescent aragonite fans (without internal lamination) and laminae composed of Mg-silicates or micrite (Fig. 9B.2). Aragonite fans are not preferentially oriented perpendicular to the substrate, and thus form irregular surfaces that produce discontinuous laminae with a thickness varying between $50 \mu \mathrm{m}$ and $1 \mathrm{~mm}$ (Fig. 10A and B). Magnesium-silicate laminae are thinner, typically a few micrometres thick (Fig. 10C to F). This fabric has been observed in flat-laminated and non-branching columns.

\section{Non-laminated fabrics}

Non-laminated fabrics are made of aragonite fans that nucleate on top of one another to form heterogeneous 'thrombolitic' and shrubby fabrics (Figs 8G, 9B.3 and 9B.4). Serpulids and bivalves locally serve as substrate for growth of aragonite 

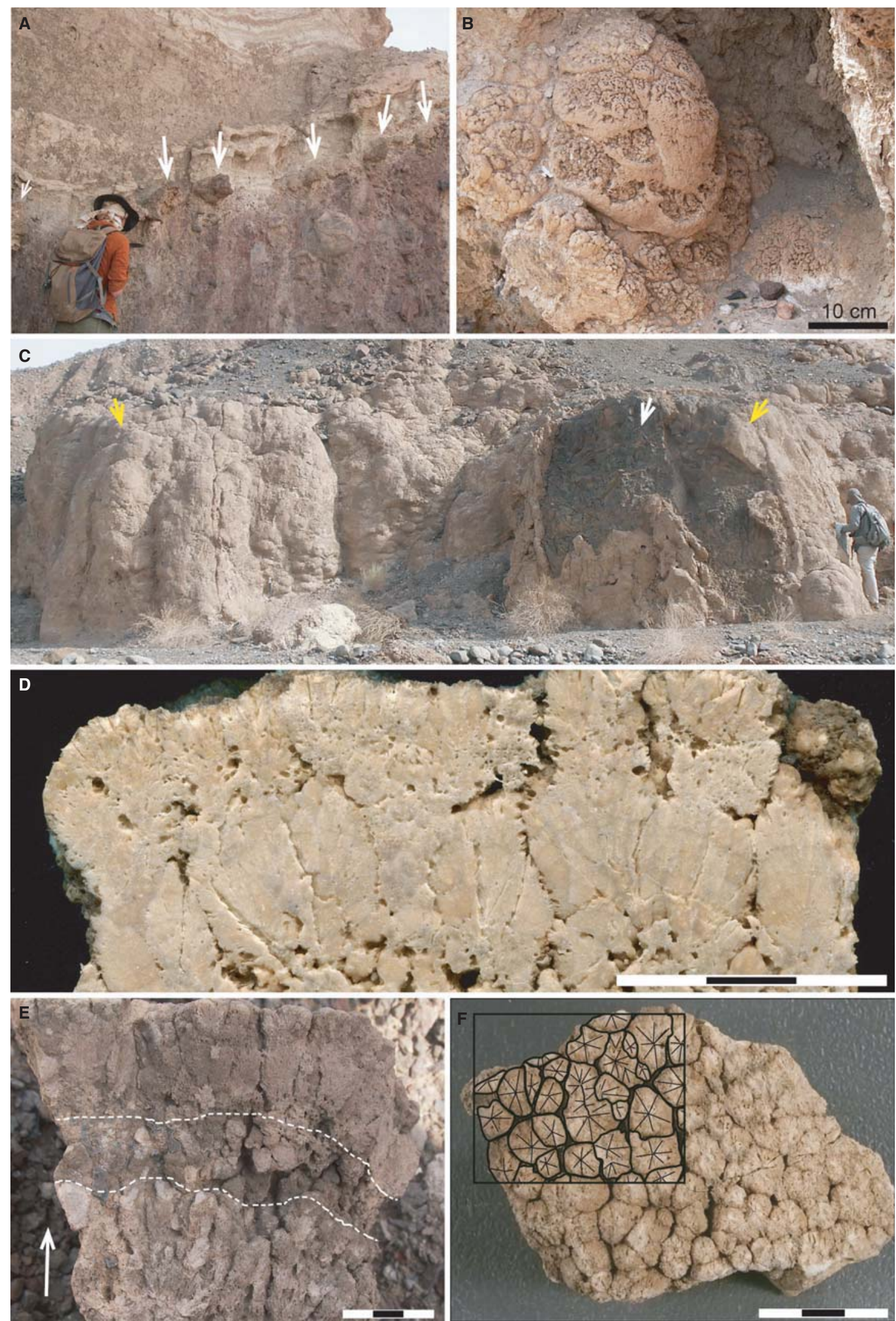
Fig. 7. Crusts and crust build-ups from deeper environments in the Upper succession. (A) Single aragonite buildups (white arrows) formed on rubble blocks on a steep rocky slope $\left(>20^{\circ}\right)$. Build-ups are covered here by layered non-marine fine-grained sediment and gypsum rich deposits (CO22 outcrop). (B) Close-up of a crust showing brain-like surfaces reflecting its internal microdigitate structure (CO22). (C) Crust (yellow arrows) covering the steep volcanic basement slope at $c a 70$ to $80 \mathrm{~m}$ palaeo-m b.s.l. (white arrow), now cropping out at the sides of a ravine. When hard substrate was available crusts covered large areas (CO27 outcrop). The person to the right of the image is $1.8 \mathrm{~m}$ tall. (D) Slab of the upper part of a shrubby microdigitate crust, showing consecutive generations of shrubs (CO22). (E) Detail of microdigitate growth within crusts. Note the growth of two generations of digits (white arrow indicates growth direction), separated by a more granular central part (between dashed lines; CO22). (F) View from underneath a microdigitate crust. Note the crust started with the nucleation and radiation of aragonite fibres at separated locations (black lines; CO22). Scale for (D) to (F) $=3 \mathrm{~cm}$.

fans. These non-laminated fabrics often contain inclusions (Fig. 11A). Usually, these inclusions are composed of Mg-silicates (Fig. 11A and B) and show a round to elongate morphology. Additionally, in some cases, siliciclastic and bioclastic grains are incorporated within the crusts. Grains can be chaotically distributed or organized along convex-up bands resulting in a crudely laminated fabric (Figs 9B.4 and 11C). These crudely laminated fabrics are especially found in the lower and central part of the crusts of the Upper succession.

\section{Spherules}

Spherules are up to $1 \mathrm{~cm}$ in diameter and have spheroidal to ellipsoidal shapes with an irregular outer surface. They are composed of radially oriented aragonite fibres (Fig. 6F) growing mostly on bioclastic nuclei (for example, serpulids; Fig. 9B.5). Aragonite fibres in spherules differ from fibrous cements formed within bioclasts. Spherule-fans are rich in Mg-silicate inclusions, while aragonite fibre-fans developed within bioclasts do not contain inclusions (Fig. 6F). Spherules may fuse together and form aggregates. Larger bioclasts (for example, bivalves) also served for nucleation. In those cases, instead of spherules, several small coalescent fans cover the surface of the bioclast.

\section{Lateral and vertical variability}

At microscopic as well as macroscopic scale, a significant lateral and vertical variability in crust fabrics is present. Variability of microfabrics within single crusts is represented by vertical and lateral transitions between isopachous lamination, irregular lamination and non-laminated fabrics. Even within single columns, lateral changes between isopachously laminated fabrics and irregularly laminated fabrics can be found.

\section{Magnesium-silicates}

Magnesium-silicates are only preserved in the Upper succession. They were identified through semi-quantitative SEM-EDS analysis on polished thin sections and selected area electron diffraction (SAED). The EDS analyses reveal the presence of $\mathrm{Mg}, \mathrm{Si}, \mathrm{O}$ and minor $\mathrm{Al}$ peaks. The $\mathrm{Mg}$ silicates occur as distinct laminae, or as inclusions within the crusts, as well as within the surrounding sediments. Larger pores are locally filled with Mg-silicates forming a matrix in which other components can be embedded. In rare cases it is possible to observe round hollow carbonate cells with diameters between $10 \mu \mathrm{m}$ and $20 \mu \mathrm{m}$ that are organized in chains and are embedded in a Mg-silicate matrix (Fig. 11D).

Based on SEM imaging, the Mg-silicates are composed of filaments with diameters between 0.1 to $0.25 \mu \mathrm{m}$ and a maximum length of $10 \mu \mathrm{m}$ (Fig. 12A). Filaments are curved and have a smooth round end. Some of the filaments form chain-like features composed of adjacent subspherical bodies (Fig. 12B). Due to the filamentous nature of the Mg-silicates, the Mg-silicate matrix is typically not massive but rather alveolar (Fig. 12C and D). The transition between Mgsilicate and aragonite fans is often characterized by an area where Mg-silicate filaments coexist with aragonite fibres (Fig. 12D to G). The Mgsilicate filaments, aggregates and laminae show fluorescence under UV-light stimulation (BP 340 to $380 \mathrm{~nm}$ for blue light), while aragonite fibres are non-fluorescent (Fig. 12H).

Transmission electron microscopy (TEM) observations reveal that, at a smaller scale, the above-described filaments consist of sepiolite fibre bundles (Fig. 11E). Individual fibres are between $10 \mathrm{~nm}$ and $20 \mathrm{~nm}$ in diameter and between $0.5 \mu \mathrm{m}$ and $2 \mu \mathrm{m}$ in length. Most fibres are straight with parallel edges; only a few longer fibres are curved (Fig. 11E). The refined lattice parameters (13.52 $\AA, 27.18 \AA$ and $5.23 \AA$ ) and the (110) d-spacing $(12 \cdot 10 \AA)$ are comparable with almost Al-free sepiolite (Fig. 11F; compare to sample MER in Sanchez del Rio et al., 2011). Although, the rings in the SAED patterns can be indexed for sepiolite, some rings are missing. The latter is explained by strong preferred 

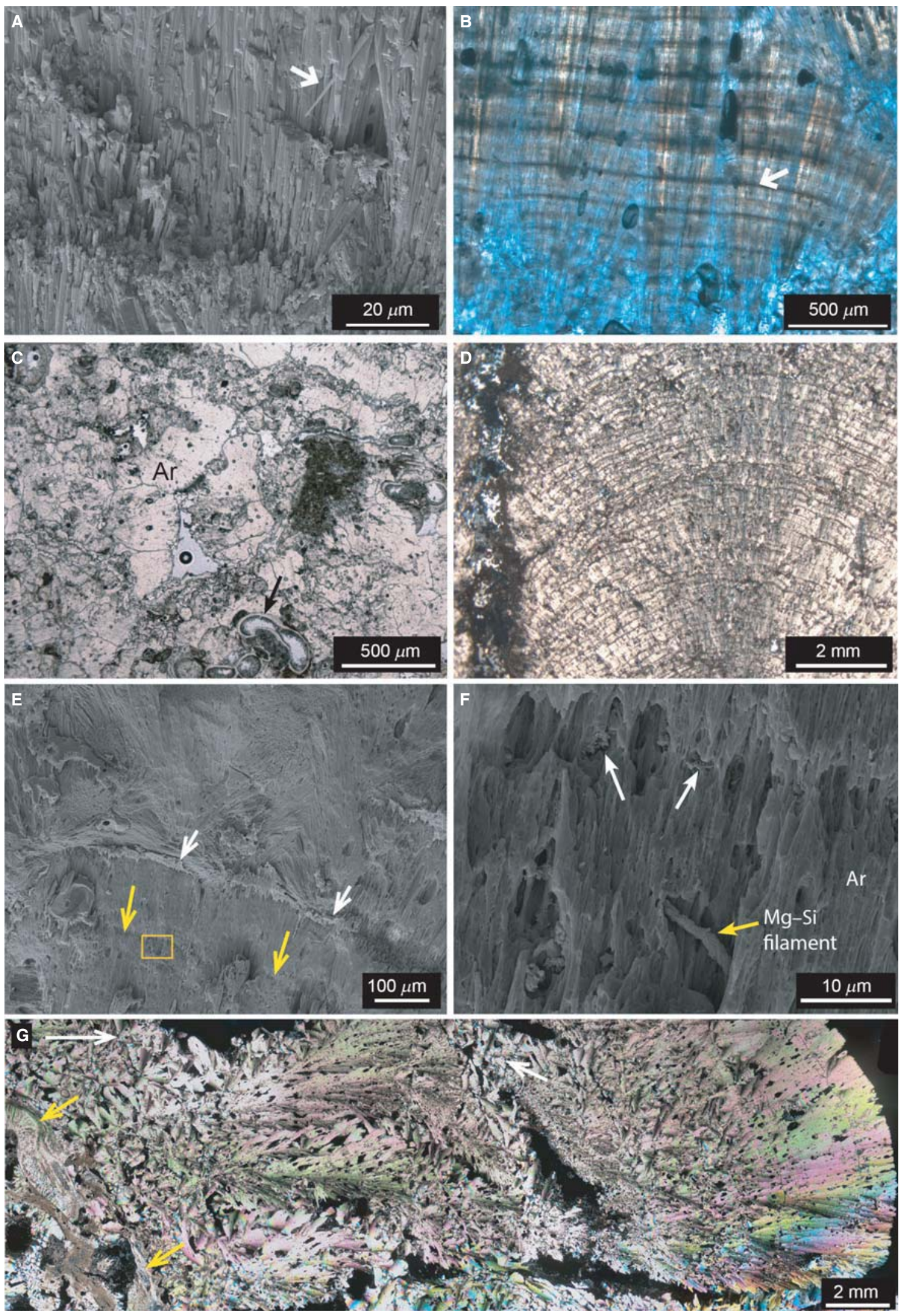
Fig. 8. (A) Scanning electron microscopy (SEM) picture of a broken surface of a crust showing aragonite fibres as the main building block of fibrous fabrics. Note that aragonite crystals increase in width along their length (white arrow; CO6 outcrop; Upper succession). (B) Photomicrograph of a thin section (ca $60 \mu \mathrm{m}$ thick) showing the basal part of an isopachously laminated crust formed by coalescent botryoids. Note the occurrence of different orders of lamination (white arrow; CO6; Lower succession). Apart from some bubbles produced by preparation (black-grey dots), the crusts are homogeneous. Blue colour is from a resin used for impregnation. (C) Aragonite fibre fans (Ar; no internal lamination) growing within a serpulid-rich crust (black arrow) (CO6; Upper succession). (D) Photomicrograph under cross-polars showing isopachous lamination, which formed by the alternation of aragonite (brighter) and porous $\mathrm{Mg}$ silicate rich laminae (darker). This is a thin section of the rock shown in Fig. 6A and D. (E) SEM-SE (SE - secondary electron) image of an etched ( $\mathrm{HCl} \mathrm{10 \% )} \mathrm{isopachously} \mathrm{laminated} \mathrm{crust} \mathrm{(CO6;} \mathrm{Upper} \mathrm{succession).} \mathrm{White} \mathrm{arrows} \mathrm{point}$ to a growth-interruption surface covered by a drape of Mg-silicate. On top of that surface, aragonite botryoids started growing again. Note the preferential dissolution occurring on a lamination plane (yellow arrows). This preferential dissolution is due to the presence of Mg-silicate inclusions. (F) Magnification of the orange rectangle in (E) shows the preferentially dissolved laminae. Magnesium-silicate inclusions (white arrows) occur at the lamination plane. These inclusions are often filamentous (yellow arrow). (G) Photomicrograph mosaic (cross-polars) showing a shallow crust composed of different microfabrics (top is indicated by the white arrow). At the base, multiple non-laminated shrubs nucleate on a bivalve shell (yellow arrow). Shrub growth is replaced by an irregularly laminated interval (white arrow) which, in turn, is covered by isopachous lamination (CO6).

orientation of the fibres, which lay mostly on their (110) face. The same preferred orientation can be inferred for the XRD samples. When exposed to the electron beam, sepiolite suffers rapid radiolitic damage (Suárez et al., 2015).

\section{Stable isotopes}

Stable isotopes measured on a coral specimen and Tridacna bivalve shells display $\delta^{13} \mathrm{C}$ values between $+1 \cdot 08 \%$ and $+1 \cdot 66 \%$. The $\delta^{13} \mathrm{C}$ values of the crusts formed in both the Upper and the
A 1.

1. Botryoids containing growth lines

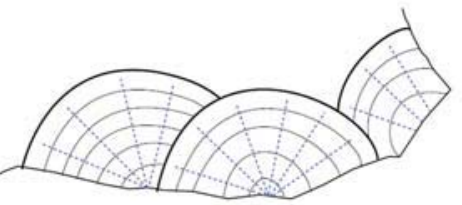

Up to 100 s $\mu \mathrm{m}$

B

1. Fans without growth lines
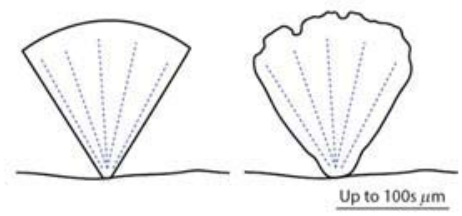

5. Spherulitic fabric
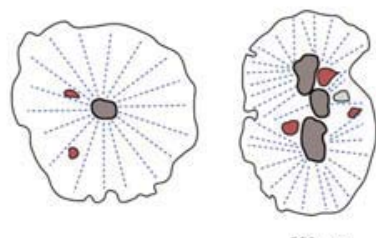

$500 \mu \mathrm{m}$
2. Flat isopachous lamination

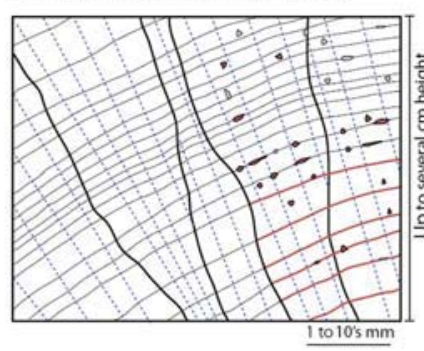

3. Non-laminated fabric
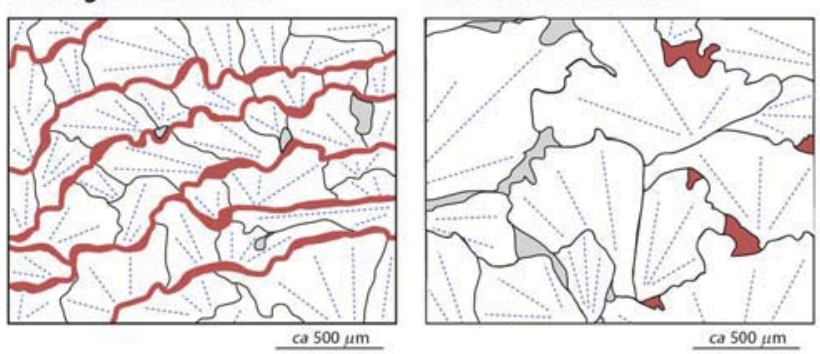

3. Isopachous lamination in columnar and digitate crusts

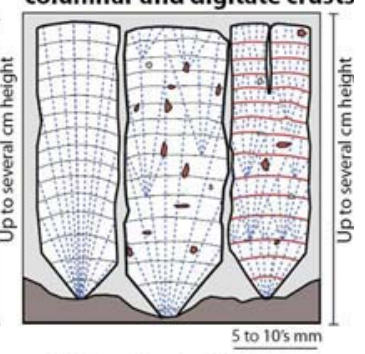

4. Non-laminated columns

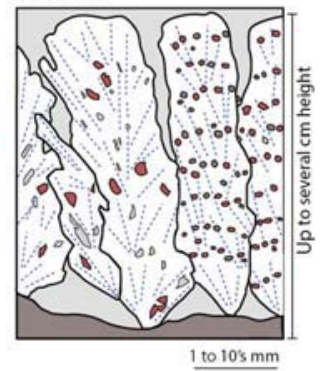

Fig. 9. Sketch showing different microfabrics found within the fibrous aragonite-dominated fabrics. 

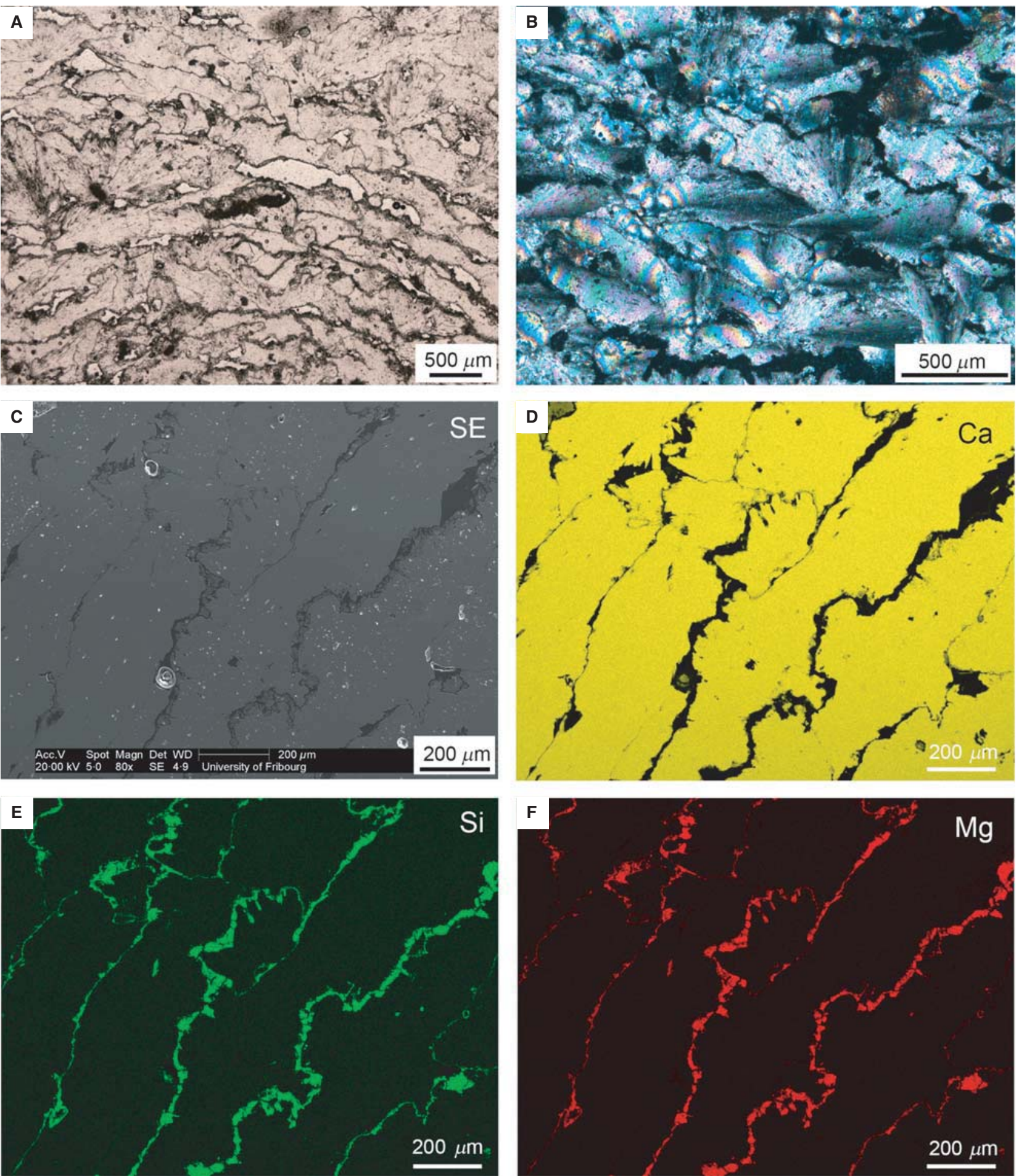

Fig. 10. (A) Photomicrograph under normal light showing irregular lamination (CO10 outcrop; Upper succession). (B) Photomicrograph under cross-polars showing irregular lamination (CO6 outcrop; Upper succession). Note that fans do not preferentially grow perpendicular to lamination as do aragonite fibres involved in isopachous lamination. (C) Scanning electron miscroscopy - secondary electron (SEM-SE) image of a thin section showing irregular lamination (CO6). (D) to (F) Elemental maps of the area shown in (C) displaying the distribution of Ca, Si and Mg. Maps demonstrate that lamination is defined by an alternation of aragonite (Ca) and Mg-silicates (Mg-Si). 

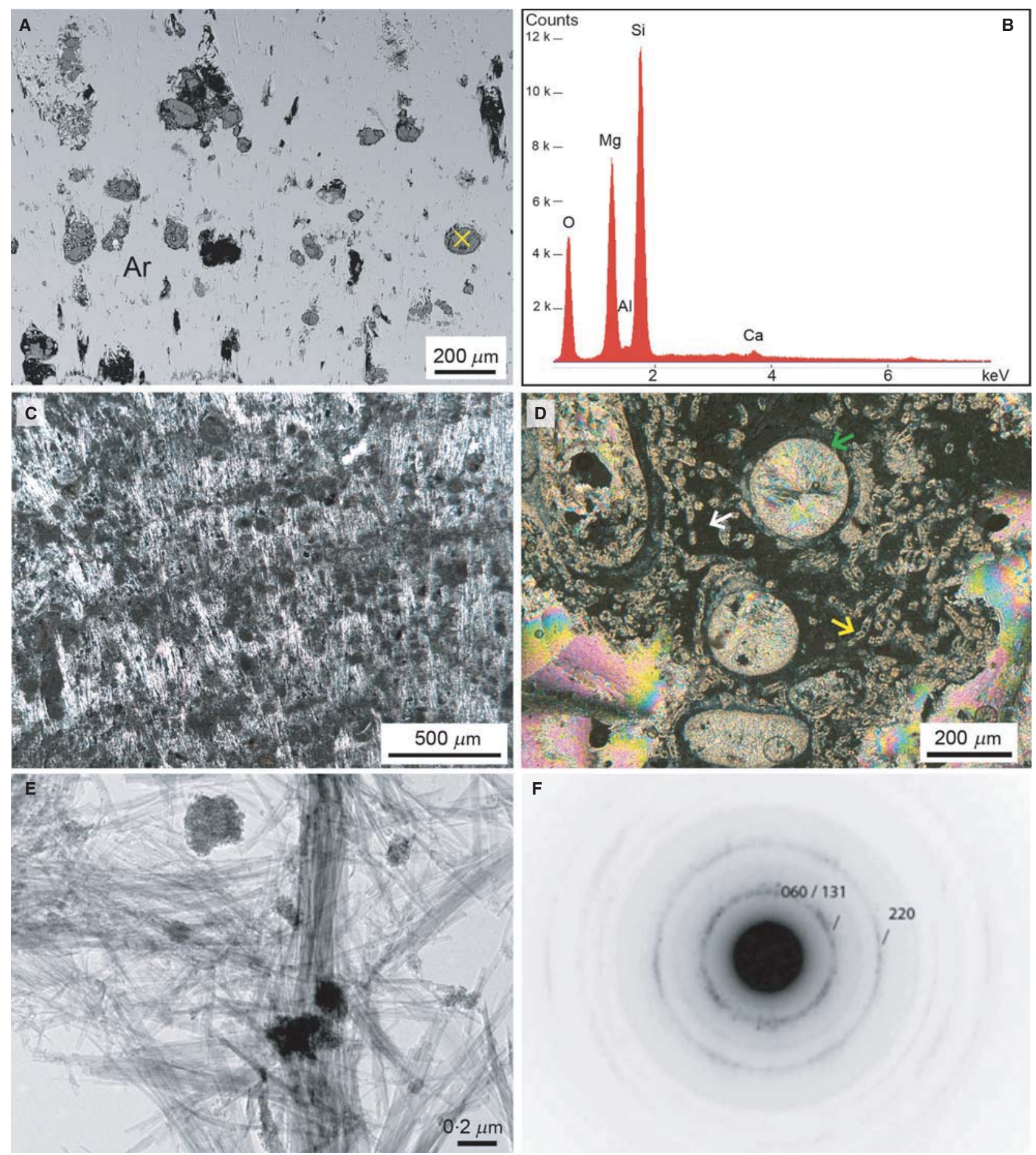

$\mathbf{F}$

Fig. 11. (A) Scanning electron microscopy - backscattered electron (SEM-BSE) image of a polished thin section showing Mg-silicate inclusions within aragonite fibre fabrics (CO6; Upper succession). (B) Scanning electron microscopy - energy dispersive spectrometry (SEM-EDS) of one Mg-silicate inclusion (yellow $x$ in 11A). (C) Photomicrograph of a crudely laminated fabric made of authigenous inclusions and trapped detrital particles embedded in an aragonite fibre matrix (CO24 outcrop; Upper succession). (D) Photomicrograph (cross-polars) showing serpulid tubes (green arrow) surrounded by chains made of unidentified hollow carbonate cells (yellow arrow) that are embedded in a matrix composed of Mg-silicates (white arrow; CO6; Upper succession). (E) Bright-field image of sepiolite fibres. The isometric flakes consist of fluorite with minor gypsum. (F) Selected area electron diffraction (SAED) pattern of sepiolite fibre aggregates (CO6 outcrop; Upper succession). The (110) ring is outshined by the central beam. 

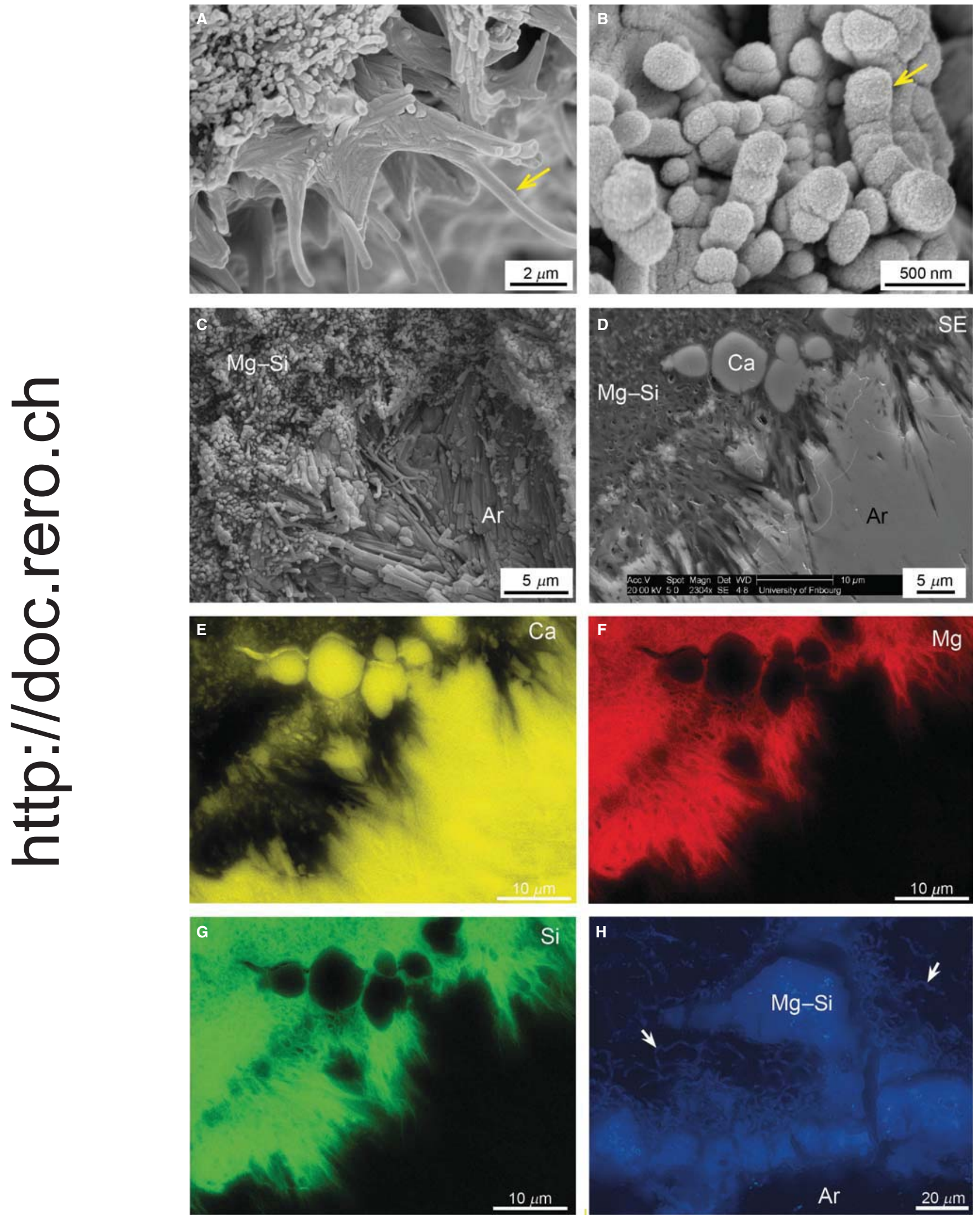
Fig. 12. Microfabrics of Mg-silicates (CO6 outcrop; Upper succession). (A) and (B) Scanning electron miscroscopy secondary electron (SEM-SE) pictures showing the morphology of Mg-silicate filaments (yellow arrow). The Mg-silicate filaments are made of smaller-scale sepiolite fibres (see Fig. 11E). (A) Curved filaments with a smooth round end resembling lithified microbes. (B) Some of the filaments form chain-like features composed of subspherical bodies. (C) SEM-SE picture of a broken surface where the contact between Mg-silicate filaments (Mg-Si) and aragonite botryoids (Ar) is visible. (D) SEM-SE image of a thin section showing the same type of transition as in (C). Note the alveolar appearance of Mg-silicate matrix. Crystals within the Mg-silicate are made of calcite (Ca). (E) to (G) Scanning electron microscopy - energy dispersive spectrometry (SEM-EDS) map of the same area of interest. Note that there is a zone of interfingering between Mg-silicate filaments and aragonite botryoids. $(\mathrm{H})$ Photomicrographs taken under UV-light. Mg-silicate (Mg-Si) embedded within aragonite fibres (Ar). Note that the Mg-silicates are fluorescent while aragonite is not. Note the elongated fluorescent Mg-silicate inclusions within aragonite matrix (white arrows).

Lower succession show systematically increased positive values which vary between $+1.51 \%$ and $+5 \cdot 25 \%$ (Fig. 13). Crusts formed in the Lower succession show overall more positive $\delta^{18} \mathrm{O}$ and more negative $\delta^{13} \mathrm{C}$ values compared to the bulk of samples of the Upper succession. Values obtained from crusts of the Upper succession include isopachously laminated, irregularly laminated and non-laminated fabrics. Interestingly, values plot close together independent of the type of fabric, implying that they formed under similar environmental conditions. All analyses were performed on aragonite powders so that mineralogical variations (for example, differences in the primary isotopic values between aragonite and calcite) should not be the reason for the observed isotopic variations.

\section{DISCUSSION AND INTERPRETATION}

\section{Depositional environment and depth distribution}

During the sea-level highstands of MIS 7 and MIS 5, the Danakil Basin was flooded with marine waters coming from the Red Sea. Coralgal framestones as well as ooid and bioclastic
Fig. 13. Cross-plot showing stable $\mathrm{C}$ and $\mathrm{O}$ isotope values of the fibrous aragonite and well-preserved invertebrate skeletons in the studied successions in Afar. The marine fauna is represented by seven Tridacna shells and one coral (black arrow).

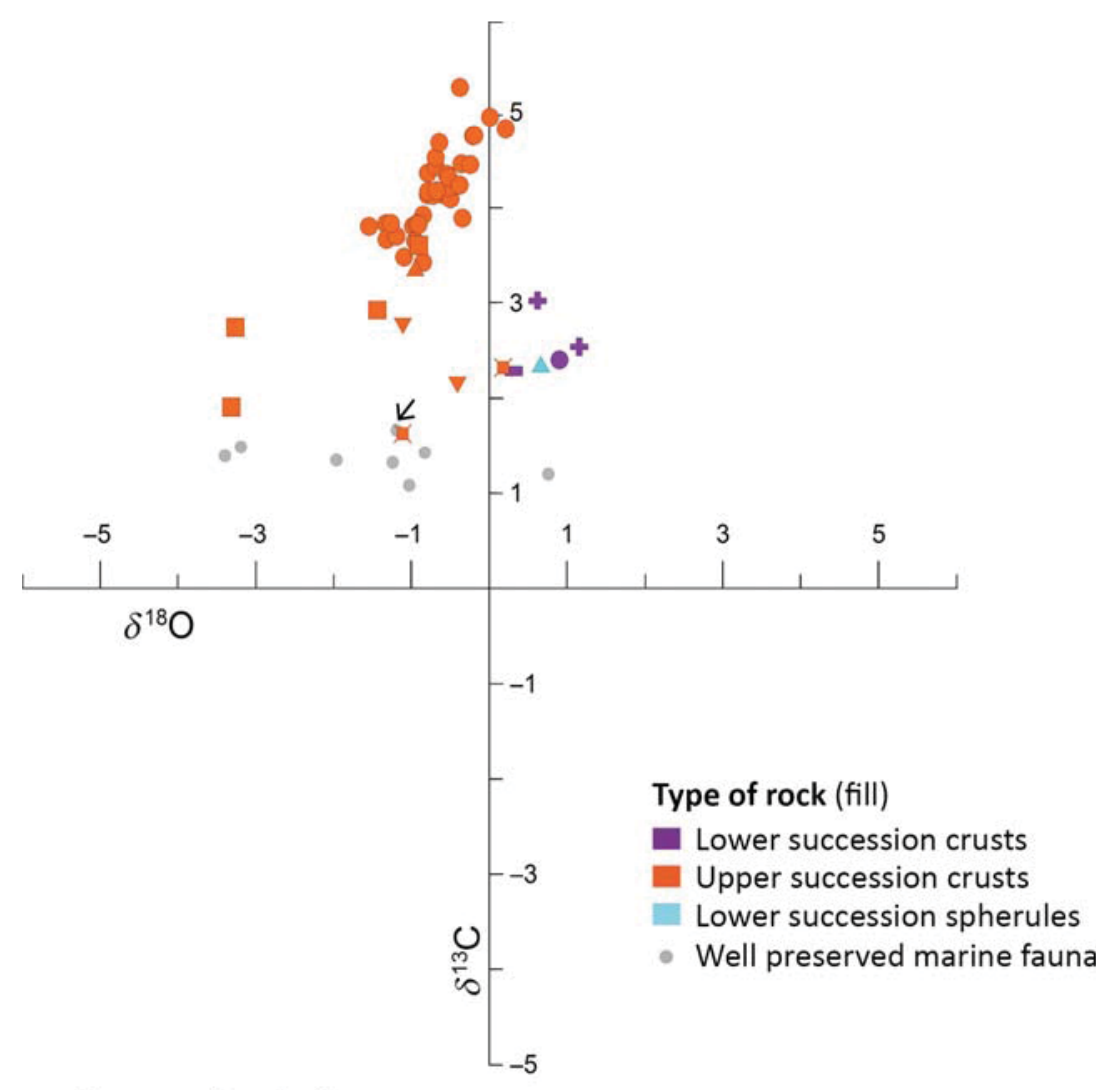

Outcrops (symbol)

$\begin{array}{llll}\square \mathrm{CO} 4 & \triangle \mathrm{CO} 10 & \square \mathrm{CO} 17 & \\ \mathrm{CO} 6 & \mathrm{CO} 14 & \nabla \mathrm{CO} 22 & \square \mathrm{CO} 24\end{array}$


grainstones and packstones were deposited along the margins (lower parts of the Lower and Upper successions; Fig. 3B). It is not yet clear where the connection to the Red Sea was located (through the Gulf of Zula; Lalou et al., 1970; Bonatti et al., 1971, or elsewhere). However, after each highstand, owing to limitation of the connection to the Red Sea, the basin developed into a restricted evaporative basin. This process was relatively rapid due to the threshold effect of the shallow gateway to the Red Sea. After the sea-level fall following MIS 5, the pathway was closed until present-day. Based on the distinct stratigraphic position of the studied aragonite crusts, occurring between marine carbonates and gypsum, these crusts are interpreted to have formed at the transition phase between open marine and restricted hypersaline conditions.

The sediments associated with the crusts and spherules on top of both marine successions are characterized by accumulations of Pirenella conica and Brachidontes pharaonis. Pirenella conica, a potamidid gastropod, is a euryhaline species that is usually found in mangrove habitats and tidal flats along the Red Sea coast (Zuschin \& Ebner, 2015). Brachidontes pharaonis, a mytilid bivalve, is often associated with Pirenella conica in intertidal settings but is also frequently found in hypersaline lakes in the Mediterranean and the Red Sea region (Safriel et al., 1980; Gianguzza et al., 1997). Brachidontes is known to survive in a wide range of temperature and salinity (Sarà et al., 2008; Zuschin \& Ebner, 2015) and thrives in salt ponds in the Mediterranean, which display salinities as high as $40 \%$ in winter and $53 \%$ in summer, and temperature fluctuations between $9^{\circ} \mathrm{C}$ in December and $30^{\circ} \mathrm{C}$ in August (Sarà et al., 2003). The disappearance of stenohaline marine fauna and the coeval occurrence of accumulations of Brachidontes and Pirenella is interpreted to indicate the initiation of hypersaline conditions. Brachidontes pharaonis is a nestling bivalve that byssally attaches to hard substrates and may form dense clusters in tidal flat settings (Zuschin \& Ebner, 2015). After death, clusters can be reworked and transported to form shell accumulations or can be buried and preserved in situ. In this study, shell valves are often articulated, implying that they were not reworked and are preserved in situ.

Lithophyllum gr. kotschyanum, the main framework builder in the upper part of the Lower succession, presently forms extensive terraces in normal-marine intertidal reef flats and shallow subtidal reef areas along the Red Sea coast of Egypt (Rasser \& Piller, 1997). These red algal frameworks serve as a substrate for the formation of extensive aragonite crusts on top of the older coralgal succession in the Danakil Depression. The position within the red algal frameworks as well as the associated mollusc fauna indicate that the crusts in the Lower succession were mainly formed in shallow subtidal settings at a similar depth as the red algal frameworks (Fig. 14).

Crusts at the top of the marine deposits of the Upper succession grew on a hard substrate provided by small coralgal reefs and/or the volcanic basement at different depths from shallow subtidal (as indicated by the coralline algal species in the reef framework) to at least 80 metres below sea-level ( $\mathrm{m}$ b.s.l.). This depth estimate is based upon the present-day difference in elevation between the reef tops and the lowest outcrops along slopes on which the crusts can be followed with no fault breaks (Fig. 14). In shallow environments, both laminated and nonlaminated crusts are associated with bivalves and serpulids, which are absent in deeper environments. While columnar and non-columnar crusts dominated in shallow settings, radial fibrous microdigitate and shrubby crusts dominated in deeper environments. This shows that there was a control on crust-type formation (or crust morphology), which was at least indirectly associated with depth (Fig. 14).

The lateral co-occurrence of crusts and aragonite spherules suggest that spherules formed under the same environmental conditions as the crusts. Spherulites are always found forming a single, discontinuous layer associated with mobile substrates in the Upper succession and more rarely in the Lower succession. Boulders, or large clasts exposed during deposition, are covered by crusts. This suggests that the nature of the substrate controls whether a crust or a spherulite is formed (Fig. 14). In the absence of hard substrate, spherules formed after nucleation of aragonite crystals on sand-sized particles, which were subsequently completely covered. In that sense, spherules can be regarded as being small isolated radial crusts. The fact that, in both successions, spherules are confined to a single layer found at a specific position, and that crusts grew coevally on hard substrate, suggests that spherules formed at the sediment/water interface. This means that, at least in this specific setting, they are primary sediments that did not result from diagenetic 


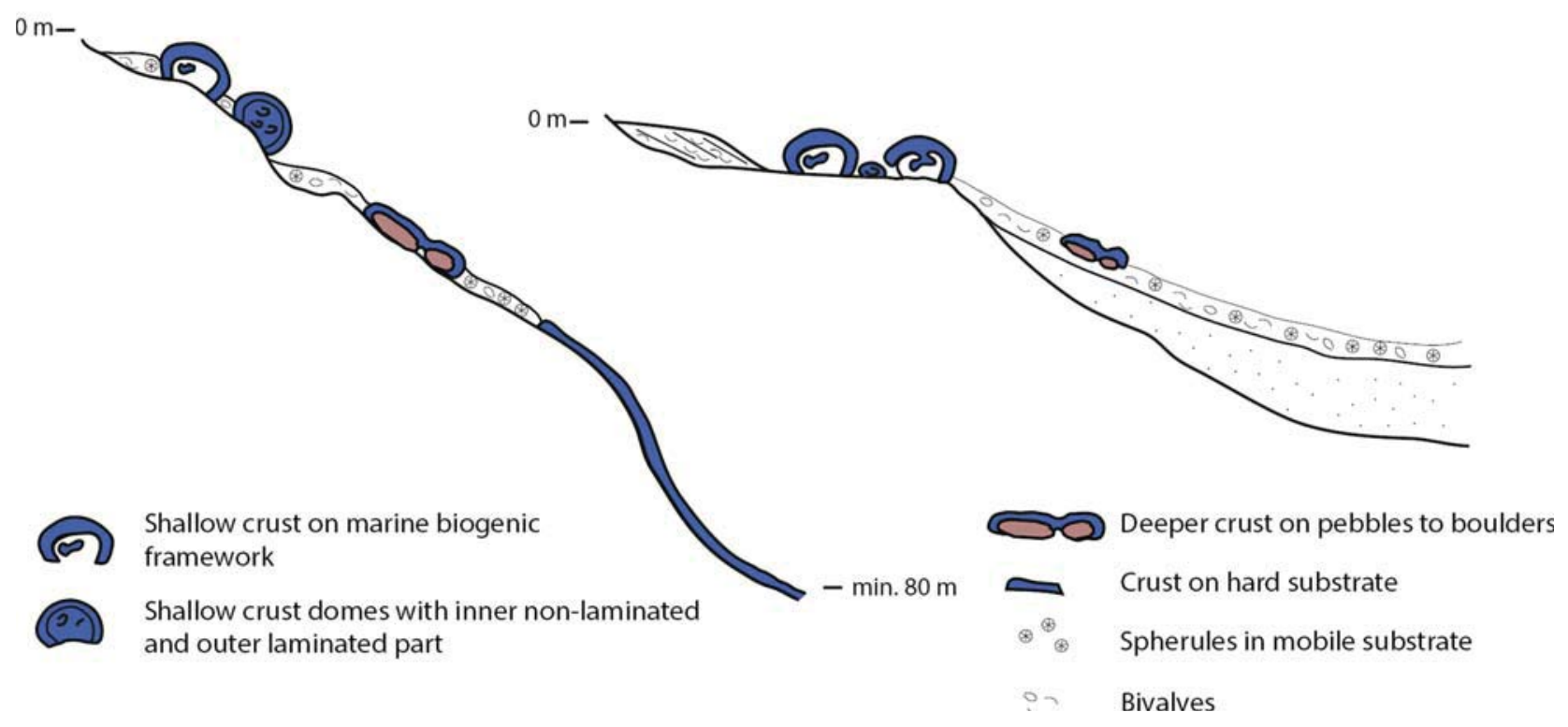

Fig. 14. Models showing depth and substrate-dependent crust distribution. Steep slopes (A) are characterized by abundant hard substrate. Crusts can form from very shallow subtidal settings to depths exceeding $80 \mathrm{~m} \mathrm{b.s.l.} \mathrm{On}$ gentle slopes (B), where hard substrate is confined to the shallow biogenic coralgal frameworks, crusts mainly formed in the shallow subtidal zone. On mobile substrate a thin (few centimetres) discontinuous spherulite layer with euryhaline molluscs was formed instead.

processes, as has been postulated for other older occurrences (Wright \& Barnett, 2015).

The isotopic values of the Danakil crusts plot close to values measured on botryoidal aragonite cements found in voids within the barrier reef in Belize at depths between $65 \mathrm{~m}$ and $120 \mathrm{~m}$ (Ginsburg \& James, 1976), on aragonitic beach rock cement in the Red Sea region (Holail \& Rashed, 1992), as well as on other modern shallow marine aragonite cements (Beier, 1985; Gonzalez \& Lohmann, 1985; Swart, 2015) precipitated in equilibrium with marine seawater. This suggests that crusts in Afar were precipitated in equilibrium with waters preserving an original marine isotopic signature and implies that the crusts formed only shortly after closure of the connection to the Red Sea and, thus, before extensive evaporation took place. The lower stable isotope values measured on corals and Tridacna shells are close to isotopic values measured on Holocene and Pleistocene (MIS 5 and 9) coral skeletons in the Red Sea (Strasser et al., 1992; Moustafa et al., 2000). Skeletons of zooxanthellate corals exhibit vital effects and, thus, display values that are negative in relation to seawater in which coral reefs are normally found (Swart, 2015).

\section{Origin of the crusts: comparison with present-day crater lakes}

Pleistocene to modern laminated fibrous aragonite fabrics have been described from non-marine stromatolites found in Niuafo'ou caldera lakes (Tonga; Kaźmierczak \& Kempe, 2006; Kremer et al., 2012), a semi-restricted marine caldera environment in Santorini (Greece; Anadón et al., 2013) and a salina environment in the Sabkha el Melah (Tunisia; Davaud et al., 1994). Additionally, in Satonda, a crater lake in Indonesia, Kempe \& Kaźmierczak (1993) and Arp et al. (2003) described microstromatolitic fabrics that can partly be compared with the laminated fabrics found in the Danakil Depression. A common feature in Recent/Holocene fibrous aragonite examples is that they generally form in waters with high alkalinity (Kempe \& Kaźmierczak, 1990; Arp et al., 2003; Kaźmierczak \& Kempe, 2006; Kremer et al., 2012), with the exception of the crusts in Sabkha el Melah that are interpreted to have formed in a restricted lagoon that evolved into an evaporitic basin. Presently, stromatolites with fibrous aragonite textures from the Niuafo'ou caldera lakes (Kremer et al., 2012) are not growing as 
actively as they were some thousands of years ago; however, calcification of coccoidal and cyanobacterial mats is still occurring as carbonate supersaturation is very high at the surface of both lakes (Vai Lahi 15.7 to 18.6 meq l$^{-1}$; Vai Si'i 6.3 to $10.9 \mathrm{meq} \mathrm{l}^{-1}$; seawater $2.32 \mathrm{meq}^{-1}$ ). While the Ca concentration is much lower, the concentration of dissolved silica in both lakes is roughly 100 times higher than in seawater (Kremer et al., 2012). These authors report an ongoing volcanic $\mathrm{CO}_{2}$ input to the waters of Vai Si'i, as well as the influence of hydrothermal activity. Kempe \& Kaźmierczak (2012) suggest that $\mathrm{CO}_{2}$-driven silicate weathering was the main process responsible for the high alkalinities of these two crater lakes.

In the Danakil Depression, volcanic activity along the Erta Ale Range is ubiquitous. Large areas in the central and marginal parts of this basin are covered with basaltic lava flows and other volcanic rocks. Therefore, it is possible that the interplay of $\mathrm{CO}_{2}$-driven silicate weathering and incipient evaporation led to the establishment of alkaline waters facilitating the precipitation of the crusts at the onset of hypersaline conditions. Due to the restriction effect and the strong volcanic activity in the basin, water could become enriched in $\mathrm{Ca}, \mathrm{Si}$ and $\mathrm{Mg}$, supporting the formation of the fibrous aragonite-Mg-silicate fabrics. As these crusts do not reach more than few tens of centimetres in thickness, it is suggested here that optimal conditions for their growth were constrained to a relatively short time interval.

\section{Microbial versus abiotic precipitation}

Although all of the crusts described in this study are dominantly made of aragonite fibres, the occurrence of different fabric types, including isopachously laminated, irregularly laminated and non-laminated fabrics within the crusts, points to diverse processes involved in crust formation. Irregularly laminated and nonlaminated fabrics evolved from the growth of coalescing crystal fans without distinctive growth lines, while isopachously laminated fabrics evolved from coalescing botryoids characterized by growth lines. In both cases, Mg-silicates may be present between the aragonite laminae, but Mg-silicates are more distinctive within the irregularly laminated and non-laminated fabrics.

Magnesium-silicates can precipitate abiotically from the water column as evaporative precipitates at $\mathrm{pH}>8.7$ (Tosca \& Masterson, 2014). Due to the lack of macroscopic and microscopic evidence for the involvement of microbes, Wright \& Barnett (2015) proposed that the extensive subsurface Early Cretaceous carbonate and Mg-silicate deposits in the South Atlantic formed mainly abiotically in highly alkaline rift lakes. Wright (2012) and Wright \& Barnett (2015) discuss the role of a freshwater catchment on a rift lake chemistry based on observations made by Cerling (1994) on lakes in the East African Rift system. These authors suggested that lakes fed by rivers draining basic volcanic terrains, coupled with thermal to ambient spring inflow, could create high $\mathrm{CO}_{2}$ input, increased alkalinity, and high concentrations of dissolved $\mathrm{Si}, \mathrm{Mg}$ and $\mathrm{Ca}$ that facilitate the precipitation of $\mathrm{Mg}$ silicate and calcite.

Magnesium-silicate precipitates have also been increasingly associated with microbial deposits in modern and Pleistocene environments. Arp et al. (2003) report Mg-silicates occurring within microstromatolites in Indonesia. These authors interpret formation of $\mathrm{Mg}$ silicate as a secondary phase formed due to seasonal dissolution of siliceous spicules and diatom tests followed by the dissolution of earlier precipitated Mg-calcite, leading to the precipitation of an amorphous Mg-silicate phase. In this example, Mg-silicates form within the microbialite, but are not part of the primary microbial precipitation. In another example, carbonate-silicate microbialites have been found forming in a basaltic sea cave in Kauai (Hawaii; Léveillé et al., 2000). The authors argue that the EPS in the microbial mats facilitated the development of a $\mathrm{Mg}-\mathrm{Si}-\mathrm{O}$ gel. A similar observation was made by Bontognali et al. (2010) who show that an early amorphous precipitate rich in $\mathrm{Mg}$ and Si formed on the walls of the EPS alveolar structure in recent microbial mats studied in Abu Dhabi. Souza-Egipsy et al. (2005) studied Mg-silicate precipitation in sand tufa on the shores of Mono Lake. These authors found a correlation between areas of biofilm presence and $\mathrm{Mg}$ absorption, and finally Mg-silicate complexation related to decay and post-mortem processes at the cyanobacteria cell walls. SouzaEgipsy et al. (2005) addressed the Mg-silica precipitates as a possible biosignature for the presence of endolithic biofilms in ancient rocks. Pacton et al. (2014) highlighted the role of viruses as templates for the precipitation of amorphous Mg-silicates within microbial mats. Burne et al. (2014) suggested that stevensite (Mg-silicate mineral) establishes the structural 
rigidity of thrombolites of Lake Clifton, Western Australia, and proposed that in a later step carbonate replaces the true primary products of Mg-silicate organomineralization, destroying any distinctive primary morphology. This is interpreted to be a possible reason why fossil microbialites do not preserve textural or isotopic biosignatures (Burne et al., 2014). Pace et al. (2016) studied microbialites formed in the Great Salt Lake where they recognized a first poorly crystallized $\mathrm{Mg}-\mathrm{Si}$ phase that precipitates on alveolar extracellular organic matrix prior to the precipitation of aragonite and later dolomite. Fibrous aragonite fabrics intercalated with laminae containing mainly silica but also $\mathrm{Mg}$ are common in modern stromatolites produced by coccoidal and filamentous cyanobacterial mats in Niuafo'ou (information extracted from the EDS spectrum in fig. 8D of Kremer et al., 2012). Lithification occurs as a result of in vivo and early post-mortem calcification of cyanobacterial filaments (Kremer et al., 2012). Nanograins of aragonite form within the capsules surrounding cells and groups of cells as well as within EPS (Kaźmierczak \& Kempe, 2004; Riding, 2006). These nanograins then serve as nucleation sites for larger needle-like aragonite crystals in fanshape arrays. As in the Lake Clifton thrombolites, during the growth of the aragonite fibres, all organic remains and features are destroyed, leaving no trace of cyanobacteria.

Mg-silicates in Afar show fluorescence under UV-light stimulation, while aragonite remains dark (Fig. 12H). This can be explained by preferential preservation of organic matter within the Mg-silicates, supporting the presence and incorporation of organic matter at the moment of the Mg-silicate formation. Accordingly, it has been observed by Kremer et al. (2012) in Niuafo'ou that, when permineralized by silica, a high percentage of organic matter remains preserved in the mineralized cell walls and mucilage sheets, while aragonite mineralization does not preserve the organic matter well. Burne et al. (2014) interpreted that nucleation of Mg-silicates in and around microbial filaments occurs when biological processes suppress $\mathrm{C}$ and $\mathrm{Ca}$ activities, leaving $\mathrm{Mg}$ to bind with silica to form a highly porous alveolar web. This process could explain the internal alveolar structure observed in Fig. $12 \mathrm{D}$ and the filamentous morphology observed under the SEM (Fig. 12A to C), indicating that the Mg-silicates found in Afar most probably result from permineralization of microbial filaments and, thus, represent microbialites.
Magnesium-silicate inclusions (Fig. 11A) are interpreted to be remains of formerly organomineralized structures that have been encased by aragonite precipitation. When aragonite fibres grow around small bioclasts, they form spherules. The fact that the fibres in the spherules contain Mg-silicate inclusions supports the interpretation that growth of spherules could have been influenced by microbial activity.

In a context of microbial influence on the formation of the crusts associated with Mg-silicates, growth of aragonite fibres from precursor aragonite nanocrysts within EPS (as described by Kaźmierczak \& Kempe, 2004) would explain the absence of growth lines within the aragonite fans forming irregularly laminated and non-laminated fabrics. This is in accordance with a scenario of aragonite fibrefans forming from nanocrysts within a given lamina, and thus independent from the cyclic variation of sea water composition occurring at the water-sediment interface. This process of formation also explains why the aragonite fans are chaotically oriented (Figs 9B.2 and 10B). The observations made by Kremer et al. (2012) in Niuafo'ou regarding the destruction of cyanobacterial remains through the growth of aragonite fans would explain why sheath remains are scarce within the crusts found in the Danakil Depression. The only probable carbonaceous microbial remains are chains of carbonate 'cells' that could correspond to permineralized microbial chains (Fig 11D); their preservation is most probably due to the fact that these chains are covered by a Mg-silicate matrix and, thus, not destroyed by aragonite fibre formation.

In some non-laminated or irregularly laminated columnar fabrics, clastic particles occur embedded in the aragonite crusts. It is possible that these particles were trapped by the action of microbial filaments and were subsequently embedded in the fibrous aragonite to form crudely laminated fabrics (Figs 9B.4 and 11C).

Although microbes are present in almost all environments on the Earth's surface, the regularity and lateral continuity of the isopachous laminae implies a predominantly abiogenic origin for the lamination (Pope \& Grotzinger, 2000; Pope et al., 2000; Riding, 2008, 2011). Accordingly, aragonite botryoids, described by Ginsburg \& James (1976) from reef-wall limestones in Belize, have been interpreted as marine cements. Continuous isopachous lamination within a crust or adjacent botryoids implies that the 
growing-front of aragonite fibres was subject to variations in environment and, thus, suggests that they formed in contact with the ambient seawater. The exact mechanisms controlling the regular pattern of isopachous laminae are not known, but individual laminae could correspond to diurnal, tidal or monsoonal cycles; or correspond to autocyclic processes caused by subsequent phases of supersaturation triggering precipitation. In the Danakil Depression, isopachously laminated columns were found from palaeo-sea level to several tens of metres of palaeo-depth, indicating that they were not restricted to shallow settings. Columns and digits of isopachously laminated crusts at depths of $80 \mathrm{~m}$ grew normal to the substrate without showing any polarity upward. This suggests that phototrophy played a subordinate role or no role at all in the formation of those crusts. A similar observation was made by Petryshyn \& Corsetti (2011) who measured the orientation of $300 \mathrm{col}-$ umns of calcitic columnar branching stromatolites covering large boulders in the Pleistocene deposits of Lake Walker in Nevada, USA. This interpretation supports the assumption that crust growth is not primarily dependent on the occurrence of photosynthetic microbes.

In the Lower succession, isopachous crusts seem to have originally consisted solely of aragonite. In contrast, in the Upper succession isopachous lamination is often characterized by the intercalation of clean aragonite with zones containing Mg-silicate filaments and/or inclusions. Although, a predominantly physicochemically (see below) dominated precipitation can be suggested for both types of isopachous lamination, the Mg-silicate inclusions and laminae were probably related to microbial activity occurring in parallel. The interpreted microbial precipitates were incorporated into the predominantly physicochemically precipitated crust.

Isotopic values of the different crusts plot relatively close together. Although different fabrics were specifically targeted with the microdrill, isotope values do not show any fabric-related signature that could be linked to microbial fractionation and would, thus, support a microbial influence in fabric formation. This is in agreement with the observations made by Burne et al. (2014) for thrombolites of Lake Clifton, where a microbial isotopic biosignature is not preserved in the carbonate fraction.

In summary, based on the available set of observations, this study suggests that the precipitation of aragonite was inevitable in the supersaturated conditions prevailing after the closure of the connection to the Red Sea, causing the precipitation of isopachously laminated crusts. However, in some cases, microbes colonized the surface of precipitation influencing microfabrics and mineralogy. Vertical, as well as lateral changes between non-laminated areas, irregular and isopachous lamination are common within single crusts. The observed changes record transitions between predominantly microbial-dominated (irregular and non-laminated fabrics) and abiotic-dominated (isopachous lamination) precipitation mechanisms. Changes from irregularly laminated to isopachous, evenly laminated stromatolites were interpreted by Pope \& Grotzinger (2000) as the result of decreasing biological influence in stromatolite deposition in the transition from normal marine to evaporitic conditions in the Palaeoproterozoic Hearne Formation (Pethei Group) in Canada. In the Danakil crusts, these processes interact in a continuum in supersaturated waters, producing hybrid microbial/abiotic crusts. It is thus, in the study area, not pertinent to assign the crusts to either 'microbial' or 'abiotic' as single genetic alternatives.

\section{Implications for the geological record}

Botryoidal crusts similar to those found in Afar, but at a larger scale, are common in extensive beds of laterally juxtaposed botryoidal fans with internal isopachous lamination found in Archaean and Palaeoproterozoic carbonate deposits (Grotzinger, 1989; Sumner \& Grotzinger, 1996, 2000, 2004; Winefield, 2000; Sumner, 2002; Riding, 2008). Ancient botryoidal fans consist of centimetric to metric radiating fibrous carbonate crystals interpreted as pseudomorphs of aragonite directly precipitated on the sea floor (Sumner \& Grotzinger, 2000, 2004; Sumner, 2002). Lamination within botryoids has been explained by sediment trapping in interstices during crystal growth or by the occurrence of organic-rich layers (Grotzinger \& Knoll, 1999). These aragonite-pseudomorph fans formed in shallow subtidal to low intertidal settings in open-marine and evaporitic systems (see Sumner, 2002, for a summary). The sustained growth of long aragonite crystals has been related to reduced sediment influx in seawater highly supersaturated with respect to aragonite (Grotzinger \& Kasting, 1993; Sumner \& Grotzinger, 2000; Winefield, 2000; Sumner, 2002), at the 
same time containing inhibitors of micrite precipitation (Sumner \& Grotzinger, 2004). The Afar crusts support the proposed scenario of neutral to alkaline $\mathrm{pH}$ of seawater to promote widespread aragonite precipitation (Sumner \& Grotzinger, 2004). By contrast, the very shallow waters in the relatively large basin in which the Danakil crusts formed were probably too oxidizing for the presence of reduced iron and manganese, suggested as possible micrite precipitation inhibitors in Neoarchean seas (Sumner \& Grotzinger, 1996, 2004; Sumner, 2002).

The crusts found in the Danakil Depression displaying isopachous lamination due to the alternation of shorter aragonite fibrous crystals and porous Mg-silicate rich laminae could be comparable to isopachous laminites described in Late Archean, Proterozoic (Grotzinger \& Knoll, 1999; Pope et al., 2000) and Palaeozoic carbonates (Grotzinger \& Knoll, 1995; Pope et al., 2000). Isopachous laminites consist of laterally continuous layers of alternating thin micritic and thicker radial fibrous layers and have been considered as largely abiotic deposits formed by precipitation of carbonate in restricted conditions at marine to evaporite transitions (Pope \& Grotzinger, 2000; Pope et al., 2000). The original fibrous carbonate, dolomitized in most cases, has been interpreted as either calcite or aragonite (Pope et al., 2000). The latter authors invoked high temperature, salinity and anoxia due to water stratification to explain the growth of isopachous-laminated stromatolites in preevaporitic conditions. The Afar examples, however exclude anoxia due to water stratification as a factor contributing to their development, since they formed at the top of coral reefs in very shallow water, and they are in some parts associated with bivalves and serpulids.

Digitate and columnar crusts with internal isopachous lamination are common in shallow as well as deep settings in Afar (Fig. 7A and B). These structures in Danakil are reminiscent of microdigitate stromatolites, which are common in Late Archean and Palaeoproterozoic carbonates, declining in the Mesoproterozoic (Grotzinger, 1989; Sumner \& Grotzinger, 1996; Grotzinger \& Knoll, 1999; Grotzinger \& James, 2000; Riding, 2008). Microdigitate stromatolites, a few millimetres in width and a few centimetres in height, can show a radial fibrous fabric and laterally continuous lamination (Hoffman, 1975; Hofmann \& Jackson, 1987); they have also been interpreted as precipitates on the sea floor
(Grotzinger \& Knoll, 1999), with diverse degrees of microbial mediation (Hofmann \& Jackson, 1987; Sami \& James, 1994). At least in some cases, the original precipitate was fibrous aragonite (Grotzinger \& Read, 1983; Grotzinger \& Knoll, 1999). The small crystal fans are separated by fine-grained layers rich in organic matter (Grotzinger \& Knoll, 1999), these could correspond to the Mg-silicate rich laminae in the Afar samples. Interestingly, silicified portions of Precambrian microdigitate stromatolites locally preserve filament moulds (Hoffman, 1975). Precambrian microdigitate stromatolites are typical of very shallow peritidal environments (Hoffman, 1975; Grotzinger \& Read, 1983; Grotzinger, 1989; Sami \& James, 1994, 1996). In Afar these crusts are found forming in depths of at least down to $80 \mathrm{~m}$; their distribution suggests that it is not only depth, but rather the availability of a stable substrate, that is a controlling parameter for the formation of digitate crusts in the Danakil Depression.

Structures composed of alternating Archaeolithoporella and fibroradial calcite replacing original acicular aragonite in the Permian Capitan limestone in New Mexico and Texas (Mazzullo \& Cys, 1978, 1983) are reminiscent of the irregularly laminated crusts in the Afar. These structures can occur as crusts or forming the cortex of nodules nucleated by skeletal fragments (Mazzullo \& Cys, 1983). Archaeolithoporella is a name applied to alternations of dark, organicrich micritic and light microsparitic laminae, tens of microns in thickness. Grotzinger \& Knoll (1995) proved that those structures, which are an important component of the Capitan reef framework, are precipitated microbialites rather than calcareous red algae, as originally interpreted (Mazzullo \& Cys, 1978).

The mesoscale morphology of some hybrid sparry fine-grained crusts (Riding, 2008) may also be reminiscent of irregular lamination in the Afar crusts. In some Precambrian coniform stromatolites, sparry layers changing laterally in thickness alternate with finer-grained thinner laminae. The spar layers may represent seafloor precipitates whereas the darker thinner laminae have been interpreted as lithified microbial mats (Knoll \& Semikhatov, 1998; Riding, 2008). The present-day composition of these Precambrian hybrid crusts does not match that of the Afar examples, but recrystallization of randomly oriented aragonite fans and alteration of Mg-silicates would lead to similar fabrics. 
The non-marine carbonates of the Cretaceous Barra Velha Formation of the Santos Basin, offshore Brazil, contain calcite shrubs and spherulites associated with Mg-silicates. These deposits are found within cyclothems interpreted to have formed in a lacustrine setting (Wright \& Barnett, 2015). According to these authors, after pluvial events causing expansion of shallow lakes, evaporation triggered abiotic precipitation of Mg-silicate gels. Within the gel, calcite nucleated to form spherulites. The Afar spherulites have a similar morphology but occur at a much smaller scale, as grains in mobile substrates. Although the spherulites in Afar are associated to Mg-silicate, they are not embedded in a Mg-silicate matrix. Instead, they often have nuclei of serpulids or other bioclasts and are embedded in a pellet-rich sediment, clearly suggesting that they formed at the sedimentwater interface, and thus are primary sediments.

Tosca \& Masterson (2014) recognized that geological examples of lithologies rich in authigenic Mg-silicate minerals are rare. This is probably due to the fact that Mg-silicates are very unstable and can be easily dissolved or replaced by diagenetic minerals. Accordingly, Mg-silicates are ubiquitous within sediments of the younger Upper succession but are rarely found in the crusts of the $c a 100 \mathrm{kyr}$ older Lower succession. Interestingly, during the last decade, microbialites containing Mg-silicates have been widely found in modern environments. It is, thus, probable that primary formation of Mg-silicates in ancient microbialites was much more important than reflected by the few examples preserved in the sedimentary record. The potential occurrence of Mg-silicates in ancient rocks has huge implications on the interpretation of fabrics and on the $\mathrm{Si}$ and $\mathrm{Mg}$ budget in diagenetic waters.

The Danakil Depression represents a rare Quaternary example where coeval growth of microdigitate, columnar and non-columnar fibrous crusts with isopachously laminated, irregularly laminated and non-laminated fabrics took place at two stratigraphic positions. The deposition of these unique diverse crusts was probably due to the special combination of marine waters enclosed in an incipient evaporitic basin, associated with active volcanism that led to the establishment of alkaline conditions. The studied crusts are spatially closely related to marine deposits, even though they clearly postdate their deposition. This has to be taken into account when detangling similar deposits in the geological record and interpreting the depositional setting of the crusts.

\section{CONCLUSIONS}

The transition from normal marine to hypersaline conditions after the restriction of the gateway between the Danakil Depression and the Red Sea led to the formation of a diverse spectrum of authigenic aragonite-fibre crusts in two successions (Lower and Upper successions), in Marine Isotope Stage 7 and Marine Isotope Stage 5, respectively. These crusts are associated with euryhaline molluscs, often found nowadays in hypersaline lakes around the Red Sea. Although oxygen isotopic values do not support extensive evaporation before precipitation of the crusts, incipient evaporation and $\mathrm{CO}_{2}$-driven weathering of the volcanic sea-floor, probably caused a short-lived phase of increased alkalinity, promoting aragonite crust precipitation before extensive evaporite deposition took over.

Good crust preservation and the excellent outcrop conditions in the Danakil Depression make it possible to study the primary fabrics prior to major diagenetic transformations, and to recognize substrate and depth dependency of the different types of deposits. This information can help to better interpret ancient counterparts with limited outcrop conditions and stronger diagenetic alteration.

Crusts only precipitated on hard substrates and preferentially on steep, unstable slopes. They formed in oxygenated waters from palaeosea-level to at least $80 \mathrm{~m}$ depth, where they grew normal to the substrate without any indication for phototrophy.

Isopachously laminated crusts precipitated without significant microbial influence due to supersaturated conditions prevailing after the closure of the connection to the Red Sea. However, the presence of Mg-silicate within the crusts, especially in non-laminated and irregularly laminated fabrics, is interpreted as the result of microbial-mediated mineralization. The diverse array of fabrics encountered in the Danakil Depression shows that microbial and abiotic precipitation interact in a continuum in oversaturated waters, producing hybrid microbial/ abiotic crusts. This assumption is based on petrographic observations but could not be corroborated by the carbon isotopic composition, because there are no distinctive facies-dependent 
variations in isotopic values which could be linked to microbial activity.

Magnesium-silicates are ubiquitous within crusts in the Upper succession. They are found as aggregates or as Mg-silicate laminae intercalated with fibrous aragonite. The Mg-silicates are easily dissolved or replaced by calcite, leaving no apparent evidence of their former presence. The absence of Mg-silicates in the older, but still geologically very young Lower succession, implies that Mg-silicate deposition may have played an important role in the formation of similar ancient crusts and that aragoniteMg-silicate lamination could have been far more common in the past than presently assumed.

\section{ACKNOWLEDGEMENTS}

This study was supported by the Swiss National Science Foundation grant (163114; SERENA Project) and TOTAL-COCARDE. Patrick Dietzsche and Alex Salzmann are thanked for the preparation of polished thin sections. Special thanks go to Martin Zuschin for the identification of the mollusc species and Torsten Venneman for isotopic analyses. Anton Eisenhauer and Volker Liebetrau are thanked for U/Th dating. We are very thankful to Allana Potash, Circum Minerals and Dallol Potash for discussions, logistical help and field accommodation during the four field campaigns in 2013, 2015, 2016 and 2017. We would also like to acknowledge the help of Lea Perrochet and Haileyesus Negga in the field during the 2016 expedition. Jean-Pierre Henriet is gratefully thanked for opening the pathway towards this project and for intensifying the collaboration with our colleagues from Addis Ababa University. We are thankful to John Grotzinger and an anonymous reviewer, as well as Assistant Editor Stephen Lokier and Chief Editor Peir Pufahl for improving the manuscript with their comments. Jacques Varet is thanked for fruitful discussions at the beginning of the project. Special thanks go also to Andre Strasser for reading an earlier version of the manuscript. Paul Wright is thanked for fruitful discussions.

\section{REFERENCES}

Aissaoui, D.M. (1985) Botryoidal aragonite and its diagenesis. Sedimentology, 32, 345-361.

Allen, M.A., Goh, F., Burns, B.P. and Neilan, B.A. (2009) Bacterial, archaeal and eukaryotic diversity of smooth and pustular microbial mat communities in the hypersaline lagoon of Shark Bay. Geobiology, 7, 82-96.

Anadón, P., Canet, C. and Friedrich, W.L. (2013) Aragonite stromatolitic buildups from Santorini (Aegean Sea, Greece): geochemical and palaeontological constraints of the caldera palaeoenvironment prior to the Minoan eruption (ca 3600 yr bp). Sedimentology, 60, 1128-1155.

Arp, G., Reimer, A. and Reitner, J. (2003) Microbialite formation in seawater of increased alkalinity, Satonda Crater Lake, Indonesia. J. Sed. Res., 73, 105-127.

ArRajehi, A., McClusky, S., Reilinger, R., Daoud, M., Alchalbi, A., Ergintav, S., Gomez, F., Sholan, J., BouRabee, F., Ogubazghi, G., Haileab, B., Fisseha, S., Asfaw, L., Mahmoud, S., Rayan, A., Bendik, R. and Kogan, L. (2010) Geodetic constraints on present-day motion of the Arabian Plate: implications for Red Sea and Gulf of Aden rifting. Tectonics, 29, TC3011-TC3020.

Atnafu, B., Kidane, T., Foubert, A., Jaramillo-Vogel, D., Schaegis, J.-C. and Henriet, J.-P. (2015) Reading history in Afar. EOS, 96, 12-15.

Awramik, S.M. and Riding, R. (1988) Role of algal eukaryotes in subtidal columnar stromatolite formation. Proc. Natl Acad. Sci. USA, 85, 1327-1329.

Ayling, B., Eggins, S., McCulloch, M.T., Chappel, J., Grün, R. and Mortimer, G. (2017) Uranium uptake history, opensystem behaviour and uranium-series ages of fossil Tridacna gigas from Huon Peninsula, Papua New Guinea. Geochim. Cosmochim. Acta, 213, 475-501.

Baker, B.H., Mohr, P.A. and Williams, L.A.J. (1972) Geology of the eastern rift system of Africa. Geol. Soc. Am. Spec. Pap., 136, 67 p.

Bannert, D., Brinckmann, J., Jordan, R., Kürsten, M., Ochse, G., Ries, H. and Schmid, F. (1971) Beiträge zur Geologie der Danakil-Senke (NE-Äthiopien). Beih. Geol. Jahrb., 116, 1-199.

Barberi, F. and Varet, J. (1970) The Erta Ale volcanic range (Danakil depression, northern Afar, Ethiopia). Bull. Volcanol., 34, 848-917.

Beier, J.A. (1985) Diagenesis of Quaternary Bahamian beachrock: petrographic and isotopic evidence. J. Sed. Res., 55, 755-761.

Benzerara, K., Meibom, A., Gautier, Q., Kaźmierczak, J., Stolarski, J., Menguy, N. and Brown, G.E. (2010) Nanotextures of aragonite in stromatolites from the quasimarine Satonda crater lake, Indonesia. In: Tufas and Speleothems: Unravelling the Microbial and Physical Controls (Eds H.M. Pedley and M. Rogerson), Geol. Soc., London, Spec. Publ., 336, 211-224.

Bonatti, E., Emiliani, C., Ostlund, G. and Rydell, H. (1971) Final desiccation of the Afar rift, Ethiopia. Science, 172, 468-469.

Bontognali, T.R., Vasconcelos, C., Warthmann, R.J., Bernasconi, S.M., Dupraz, C., Strohmenger, C.J. and McKenzie, J.A. (2010) Dolomite formation within microbial mats in the coastal sabkha of Abu Dhabi (United Arab Emirates). Sedimentology, 57, 824-844.

Bosak, T., Knoll, A.H. and Petroff, A.P. (2013) The meaning of stromatolites. Annu. Rev. Earth Planet. Sci., 41, 21-44.

Brachert, T.C., Vescogni, A., Bosellini, F.R., Reuter, M. and Mertz-Kraus, R. (2007) High salinity variability during the early Messinian revealed by stable isotope signatures from vermetid and Halimeda reefs of the Mediterranean region. Geol. Romana, 40, 51-66.

Braga, J.C., Martín, J.M. and Riding, R. (1995) Controls on microbial dome fabric development along a carbonate- 
siliciclastic shelf-basin transect, Miocene, S.E. Spain. Palaios, 10, 347-361.

Brinckmann, J. and Kürsten, M. (1971) Stratigraphie und Tektonik der Danakil-Senke (NE-Äthiopien). Beih. Geol. Jahrb., 116, 5-86.

Burne, R.V., Moore, L.S., Christy, A.G., Troitzsch, U., King, P.L., Carnerup, A.M. and Hamilton, P.J. (2014) Stevensite in the modern thrombolites of Lake Clifton, Western Australia: a missing link in microbialite mineralization? Geology, 42, 575-578.

Cerling, T.E. (1994) Chemistry of closed basin lake waters: a comparison between African Rift Valley and some central North American rivers and lakes. In: Global Geological Record of Lake Basins (Eds E.H. Gierlowski-Kordesch and K. Kelts), 1, 29-30. Cambridge University Press, Cambridge.

Cheng, H., Edwards, R.L., Hoff, J., Gallup, C.D., Richards, D.A. and Asmeron, Y. (2000) The half-lives of uranium234 and thorium-230. Chem. Geol., 169, 17-33.

Davaud, E., Strasser, A. and Jedoui, Y. (1994) Stromatolite and serpulid bioherms in a Holocene restricted lagoon (Sabkha el Melah, southeastern Tunisia). In: Phanerozoic Stromatolites II (Eds. J. Bertrand-Sarfati and C. Monty), pp. 131-151. Springer Science + Business Media, Dordrecht.

Dill, R.F., Shinn, E.A., Jones, A.T., Kelly, K. and Steinen, R.P. (1986) Giant subtidal stromatolites forming in normal salinity waters. Nature, 324, 55-58.

Dravis, J.J. (1983) Hardened subtidal stromatolites, Bahamas. Science, 219, 385-386.

Dupraz, C., Reid, R.P., Braissant, O., Decho, A.W., Norman, R.S. and Visscher, P.T. (2009) Processes of carbonate precipitation in modern microbial mats. Earth-Sci. Rev., 96, 141-162.

Feldmann, M. and McKenzie, J.A. (1997) Messinian stromatolite-thrombolite associations, Santa Pola, SE Spain: an analogue for the Palaeozoic? Sedimentology, 44, 893-914.

Gianguzza, P., Chemello, R. and Riggio, S. (1997) Segnalazione di Brachidontes pharaonis (P. Fischer, 1870) (Bivalvia, Mytilidae) nella salina di Marsala e considerazioni sulla distribuzione della specie in Mediterraneo. Boll. Malac., 33, 169-172.

Ginsburg, R.N. and James, N.P. (1976) Submarine botryoidal aragonite in Holocene reef limestones, Belize. Geology, 4, 431-436.

Gonzalez, L.A. and Lohmann, K.C. (1985) Carbon and oxygen isotopic composition of Holocene reefal carbonates. Geology, 13, 811-814.

Grey, K. (1989) Handbook for the study of stromatolites and associated structures. Stromatolite Newsl., 14, 82-171.

Grotzinger, J.P. (1989) Facies and evolution of Precambrian carbonate depositional systems: emergence of the modem platform archetype. In: Controls on Carbonate Platform and Basin Development (Eds P.D. Crevello, J.L. Wilson, J.E. Sarg and J.E. Read), SEPM Spec. Publ., 44, 79-106.

Grotzinger, J.P. and James, N.P. (2000) Precambrian carbonates: evolution of understanding. In: Carbonate Sedimentation and Diagenesis in the Evolving Precambrian World (Eds J.P. Grotzinger and N.P. James), SEPM Spec. Publ., 67, 3-20.

Grotzinger, J.P. and Kasting, J.F. (1993) New constraints on Precambrian ocean composition. J. Geol., 101, 235-243.

Grotzinger, J.P. and Knoll, A.H. (1995) Anomalous carbonate precipitates: is the Precambrian the key to the Permian? Palaios, 10, 578-596.

Grotzinger, J.P. and Knoll, A.H. (1999) Stromatolites in Precambrian carbonates: evolutionary mileposts or environmental dipsticks? Annu. Rev. Earth Planet. Sci., 27, 313-358.

Grotzinger, J.P. and Read, J.F. (1983) Evidence for primary aragonite precipitation, lower Proterozoic (1.9-Ga) Rocknest Dolomite, Wopmay Orogen, Northwest Canada. Geology, 11, 710-713.

Grotzinger, J.P. and Rothman, D.H. (1996) An abiotic model for stromatolite morphogenesis. Nature, 383, 423-425.

Hammond, J.O.S., Kendall, J.M., Stuart, G.W., Keir, D., Ebinger, C., Ayele, A. and Belachew, M. (2011) The nature of the crust beneath the Afar triple junction: evidence from receiver functions. Geochem. Geophys. Geosyst., 12, Q12004. https://doi.org/10.1029/2011GC003738.

Hoffman, P.F. (1975) Shoaling-upward shale-to-dolomite cycles in the Rocknest Formation (lower Proterozoic), Northwest Territories, Canada. In: Tidal Deposits (Ed. R.N. Ginsburg), pp. 257-265. Springer-Verlag. Berlin, Heidelberg.

Hofmann, H.J. and Jackson, J.D. (1987) Proterozoic ministromatolites with radial fibrous fabric. Sedimentology, 34, 963-971.

Hofmann, C., Courtillot, V., Feraud, G., Rochette, P., Yirgu, G., Ketefo, E. and Pik, R. (1997) Timing of the Ethiopian flood basalt event and implications for plume birth and global change. Nature, 389, 838-841.

Holail, H. and Rashed, M. (1992) Stable isotopic composition of carbonate cemented recent beachrock along the Mediterranean and the Red Sea coasts of Egypt. Mar. Geol., 106, 141-148.

Holwerda, J.G. and Hutchinson, R.W. (1968) Potash-bearing evaporites in the Danakil area, Ethiopia. Econ. Geol., 63, 124-150.

Hutchinson, R.W. and Engels, G.G. (1970) Tectonic significance of regional geology and evaporite lithofacies in northeastern Ethiopia. Phil. Trans. Roy. Soc. London, 267, 313-329.

Kalkowsky, E. (1908) Oolith und Stromatolith im norddeutschen Buntsandstein. Z. Deut. Geol. Ges., 60, 68125.

Kaźmierczak, J. and Kempe, S. (2004) Microbialite formation in seawater of increased alkalinity, Satonda Crater Lake, Indonesia: discussion. J. Sed. Res., 74, 314-317.

Kaźmierczak, J. and Kempe, S. (2006) Genuine modern analogues of Precambrian stromatolites from caldera lakes of Niuafo'ou Island, Tonga. Naturwissenschaften, 93, 119-126.

Keir, D., Bastow, I.D., Pagli, C. and Chambers, E.L. (2013) The development of extension and magmatism in the Red Sea rift of Afar. Tectonophysics, 607, 98-114.

Kempe, S. and Degens, E.T. (1985) An early soda ocean? Chem. Geol., 53, 95-108.

Kempe, S. and Kaźmierczak, J. (1990) Chemistry and stromatolites of the sea-linked Satonda Crater Lake, Indonesia: a recent model for the Precambrian sea? Chem. Geol., 81, 299-310.

Kempe, S. and Kaźmierczak, J. (1993) Satonda Crater Lake, Indonesia: hydrogeochemistry and biocarbonates. Facies, 28, 1-31.

Kempe, S. and Kaźmierczak, J. (2011) Soda ocean hypothesis. In: Encyclopedia of Geobiology (Eds. J. Reitner and V. Thiel), pp. 829-833. Springer, The Netherlands.

Kempe, S. and Kaźmierczak, J. (2012) Terrestrial analogues for early planetary oceans: Niuafo'ou caldera lakes (Tonga) and their geology, water chemistry, and stromatolites. In: Life on Earth and Other Planetary Bodies (Eds. A. Hanslmeier, S. Kempe and J. Seckbach), pp. 195-234. Springer, The Netherlands. 
Kennard, J.M. and James, N.P. (1986) Thrombolites and stromatolites; two distinct types of microbial structures. Palaios, 1, 492-503.

Knoll, A.H. and Semikhatov, M.A. (1998) The genesis and time distribution of two distinctive Proterozoic stromatolite microstructures. Palaios, 13, 408-422.

Kremer, B., Kaźmierczak, J., Lukomska-Kowalczyk, M. and Kempe, S. (2012) Calcification and Silicification: fossilization potential of cyanobacteria from Stromatolites of Niuafo'ou's Caldera Lakes (Tonga) and implications for the early fossil record. Astrobiology, 12, 535-548.

Lalou, C., Nguyen, H.V., Faure, H. and Mareira, L. (1970) Datation par la méthode uranium- thorium des hauts niveaux de coraux de la dépression de l'Afar (Éthiopie). Rev. Géogr. Phys. Géol. Dynam., 12, 3-8.

Léveillé, R.J., Fyfe, W.S. and Longstaffe, F.J. (2000) Geomicrobiology of carbonate-silicate microbialites from Hawaiian basaltic sea caves. Chem. Geol., 169, 339-355.

Logan, B.W. (1961) Cryptozoon and associate stromatolites from the Recent, Shark Bay, Western Australia. J. Geol., 69, 517-533.

Makris, J. and Ginzburg, A. (1987) The Afar Depression: transition between continental rifting and sea-floor spreading. Tectonophysics, 141, 199-214.

Manighetti, I., Tapponnier, P., Courtillot, V., Gruszow, S. and Gillot, P.Y. (1997) Propagation of rifting along the Arabia-Somalia plate boundary: the gulfs of Aden and Tadjoura. J. Geophys. Res., 102, 2681-2710.

Mazzullo, S.J. and Cys, J.M. (1978) Archaeolithoporellaboundstones and marine aragonite cements, Permian Capitan reef, New Mexico and Texas, USA. Neues Jb. Paläontol. Monat., 10, 600-611.

Mazzullo, S.J. and Cys, J.M. (1983) Unusual algal-crystalline carbonate coated grains from the capitan reef (Permian, Guadalupian), New Mexico, USA. In: Coated Grains (Ed. T.M. Peryt), pp. 599-608. Springer-Verlag, Berlin, Heidelberg.

McClusky, S., Reilinger, R., Ogubazghi, G., Amleson, A., Healeb, B., Vernant, P., Sholan, J., Fisseha, S., Asfaw, L., Bendick, R. and Kogan, L. (2010) Kinematics of the southern Red Sea-Afar Triple Junction and implications for plate dynamics. Geophys. Res. Lett., 37, L05301. https://doi.org/10.1029/2009GL041127.

Moustafa, Y.A., Pätzold, J., Loya, Y. and Wefer, G. (2000) Mid-Holocene stable isotope record of corals from the northern Red Sea. Int. J. Earth Sci., 88, 742-751.

Pace, A., Bourillot, R., Bouton, A., Vennin, E., Galaup, S., Bundeleva, I., Patrier, P., Dupraz, C., Thomazo, C., Sansjofre, P., Yokoyama, Y., Franceschi, M., Anguy, Y., Pigot, L., Virgone, A. and Visscher, P.T. (2016) Microbial and diagenetic steps leading to the mineralisation of Great Salt Lake microbialites. Sci. Rep., 6, 31495. https://doi. org/10.1038/srep31495.

Pacton, M., Wacey, D., Corinaldesi, C., Tangherlini, M., Kilburn, M.R., Gorin, G.E., Danovaro, R. and Vasconcelos, C. (2014) Viruses as new agents of organomineralization in the geological record. Nature Commun., 5, 4298. https://doi.org/10.1038/ncomms5298.

Paerl, H.W., Steppe, T.F. and Reid, R.P. (2001) Bacterially mediated precipitation in marine stromatolites. Environ. Microbiol., 3, 123-130.

Petryshyn, V.A. and Corsetti, F.A. (2011) Analysis of growth directions of columnar stromatolites from Walker Lake, western Nevada. Geobiology, 9, 425-435.
Pope, M.C. and Grotzinger, J.P. (2000) Controls on fabric development and morphology of tufas and stromatolites, uppermost Pethei Group (1.8 Ga), Great Slave Lake, Northwest Canada. In: Carbonate Sedimentation and Diagenesis in the Evolving Precambrian World (Eds J.P. Grotzinger and N.P. James), SEPM Spec. Publ., 67, 103-121.

Pope, M.C., Grotzinger, J.P. and Schreiber, B.C. (2000) Evaporitic subtidal stromatolites produced by in situ precipitation: textures, facies associations, and temporal significance. J. Sed. Res., 70, 1139-1151.

Raaben, M.E. (2006) Dimensional parameters of columnar stromatolites as a result of stromatolite ecosystem evolution. Stratigr. Geol. Correl., 14, 150-163.

Rasser, M. and Piller, W.E. (1997) Depth distribution of calcareous encrusting associations in the northern Red Sea (Safaga, Egypt) and their geological implications. Proceedings of the 8th International Coral Reef Symposium, 1, 743-748.

Reid, R.P. and Browne, K.M. (1991) Intertidal stromatolites in a fringing Holocene reef complex, Bahamas. Geology, 19, 15-18.

Reid, R.P., Macintyre, I.G., Browne, K.M., Steneck, R.S. and Miller, T. (1995) Modern marine stromatolites in the Exuma Cays, Bahamas: uncommonly common. Facies, 33, 1-17.

Reid, R.P., Visscher, P.T., Decho, A.W., Stolz, J.F., Bebout, B.M., Dupraz, C., Macintyre, I.G., Paerl, H.W., Pinckney, J.L., Prufert-Bebout, L., Steppe, T.F. and DesMarais, D.J. (2000) The role of microbes in accretion, lamination and early lithification of modern marine stromatolites. Nature, 406, 989-992.

Reid, R.P., James, N.P., Macintyre, I.G. and Dupraz, C.P. (2003) Shark Bay stromatolites: microfabrics and reinterpretation of origins. Facies, 49, 299-324.

Riding, R. (2006) Cyanobacterial calcification, carbon dioxide concentrating mechanisms, and ProterozoicCambrian changes in atmospheric composition. Geobiology, 4, 299-316.

Riding, R. (2008) Abiogenic, microbial and hybrid authigenic carbonate crusts: components of Precambrian stromatolites. Geol. Croat., 61, 73-103.

Riding, R. (2011) The nature of stromatolites: 3,500 million years of history and a century of research. In: Advances in Stromatolite Geobiology (Eds J. Reitner, N-V. Quéric and G. Arp), Lecture Notes in Earth Sciences, 131, 29-74. Springer-Verlag, Berlin, Heidelberg.

Riding, R., Awramik, S.M., Winsborough, B.M., Griffin, K.M. and Dill, R.F. (1991) Bahamian giant stromatolites: microbial composition of surface mats. Geol. Mag., 128, 227-234.

Safriel, U.N., Gilboa, A. and Felsenburg, T. (1980) Distribution of rocky intertidal mussels in the Red Sea coasts of Sinai, the Suez Canal and the Mediterranean coast of Israel, with special reference to recent colonizers. J. Biogeogr., 7, 39-62.

Sami, T.T. and James, N.P. (1994) Peritidal carbonate platform growth and cyclicity in an early Proterozoic foreland basin, upper Pethei Group, northwest Canada. J. Sed. Res., B64, 111-131.

Sami, T.T. and James, N.P. (1996) Synsedimentary cements as Paleoproterozoic platform building blocks, Pethei Group, northwestern Canada. J. Sed. Res., 66, 209-222.

Sanchez del Rio, M., Garcia-Romero, E., Suarez, M., Da Silva, I., Fuentes-Montero, L. and Martinez-Criado, G. (2011) Variability in sepiolite: diffraction studies. Am. Mineral., 96, 1443-1454. 
Sarà, G., Vizzini, S. and Mazzola, A. (2003) Sources of carbon and dietary habits of new Lessepsian entry Brachidontes pharaonis (Bivalvia, Mytilidae) in the western Mediterranean. Mar. Biol., 143, 713-722.

Sarà, G., Romano, C., Widdows, J. and Staff, F.J. (2008) Effect of salinity and temperature on feeding physiology and scope for growth of an invasive species (Brachidontes pharaonis-Mollusca: Bivalvia) within the Mediterranean sea. J. Exp. Mar. Biol. Ecol., 363, 130-136.

Semikhatov, M.A., Gebelein, C.D., Cloud, P., Awramik, S.M. and Benmore, W.C. (1979) Stromatolite morphogenesisprogress and problems. Can. J. Earth Sci., 19, 992-1015.

Souza-Egipsy, V., Wierzchos, J., Ascaso, C. and Nealson, K.H. (2005) Mg-silica precipitation in fossilization mechanisms of sand tufa endolithic microbial community, Mono Lake (California). Chem. Geol., 217, 77-87.

Strasser, A., Strohmenger, C., Davaud, E. and Bach, A. (1992) Sequential evolution and diagenesis of Pleistocene coral reefs (South Sinai, Egypt). Sed. Geol., 78, 59-79.

Suárez, M., Morales, J., Torrespardo, A. and GarcíaRomero, E. (2015) A micromorphological study on natural and folded sepiolite. Eur. J. Mineral., 27, 81-90.

Sumner, D. Y. (2002) Decimetre-thick encrustations of calcite and aragonite on the sea-floor and implications for Neoarchean and Neoproterozoic ocean chemistry. In: Precambrian Sedimentary Environments: A Modern Approach to Ancient Depositional Systems (Eds W. Altermann and P.L. Corcoran). IAS Spec. Publ., 33, 107-120.

Sumner, D.Y. and Grotzinger, J.P. (1996) Were kinetics of Archean calcium carbonate precipitation related to oxygen concentration. Geology, 24, 119-122.

Sumner, D.Y. and Grotzinger, J.P. (2000) Late Archean aragonite precipitation: petrography, facies associations, and environmental significance. In: Carbonate Sedimentation and Diagenesis in the Evolving Precambrian World (Eds J.P. Grotzinger and N.P. James), SEPM Spec. Publ., 67, 123-144.

Sumner, D.Y. and Grotzinger, J.P. (2004) Implications for Neoarchaean ocean chemistry from primary carbonate mineralogy of the Campbellrand-Malmani Platform, South Africa. Sedimentology, 51, 1273-1299.

Suosaari, E.P., Reid, R.P., Playford, P.E., Foster, J.S., Stolz, J.F., Casaburi, G., Hagan, P.D., Chirayath, V., Macintyre, I.G., Planavsky, N.J. and Eberli, G.P. (2016) New multiscale perspectives on the stromatolites of Shark Bay, Western Australia. Sci. Rep., 6, 20557. https://doi.org/10. 1038/srep20557.
Swart, P. (2015) The geochemistry of carbonate diagenesis: the past, present and future. Sedimentology, 62, 12331304.

Tosca, N.J. and Masterson, A.L. (2014) Chemical controls on incipient $\mathrm{Mg}$-silicate crystallization at $25^{\circ} \mathrm{C}$ : implications for early and late diagenesis. Clay Mineral., 49, 165-194.

Varet, J. and Gasse, F. (1978) Geology of central and southern Afar (Ethiopia and Djibouti Republic): Paris. Editions du Centre National de la Recherche Scientifique, Report.

Visscher, P.T., Reid, R.P., Bebout, B.M., Hoeft, S.E., Macintyre, I.G. and Thompson, J.A. (1998) Formation of lithified micritic laminae in modern marine stromatolites (Bahamas): the role of sulfur cycling. Am. Mineral., 83, 1482-1493.

Visscher, P.T., Reid, R.P. and Bebout, B.M. (2000) Microscale observations of sulfate reduction: correlation of microbial activity with lithified micritic laminae in modern marine stromatolites. Geology, 28, 919-922.

Winefield, P.R. (2000) Development of late Paleoproterozoic aragonite seafloor cements in the McArthur Group, northern Australia. In: Carbonate Sedimentation and Diagenesis in the Evolving Precambrian World (Eds J.P. Grotzinger and N.P. James), SEPM Spec. Publ., 67, 145159.

Wright, V.P. (2012) Lacustrine carbonates in rift settings: the interaction of volcanic and microbial processes on carbonate deposition. In: Advances in Carbonate Exploration and Reservoir Analysis (Eds J. Garland, J.E. Neilson, S.E. Laubach and K.J. Whidden), Geol. Soc., London, Spec. Publ., 370, 39-47.

Wright, V.P. and Barnett, A.J. (2015) An abiotic model for the development of textures in some South Atlantic early Cretaceous lacustrine carbonates. In: Microbial Carbonates in Space and Time: Implications for Global Exploration and Production (Eds D.W.J. Bosence, K. Gibbons, D.P. Le Heron, T. Pritchard and B. Vining), Geol. Soc., London, Spec. Publ., 418, 209-219.

Zuschin, M. and Ebner, C. (2015) Actuopaleontological characterization and molluscan biodiversity of a protected tidal flat and shallow subtidal at the northern Red Sea. Facies, 61, 1-13. 